\title{
Biological Role of Dystroglycan in Schwann Cell Function and Its Implications in Peripheral Nervous System Diseases
}

\author{
Toshihiro Masaki1, 2 and Kiichiro Matsumura ${ }^{3}$ \\ ${ }^{1}$ Centre for Neuroregeneration, University of Edinburgh, Chancellor's Building, 49 Little France Crescent, \\ Edinburgh EH16 4SB, UK \\ ${ }^{2}$ Faculty of Medical Sciences, Teikyo University of Science, 2-2 Senju-Sakuragi, Adachi-ku, Tokyo 120-0045, Japan \\ ${ }^{3}$ Department of Neurology and Neuroscience, Teikyo University, 2-11-1 Kaga, Itabashi-ku, Tokyo 173-8605, Japan \\ Correspondence should be addressed to Toshihiro Masaki, t-masaki@ntu.ac.jp
}

Received 22 October 2009; Accepted 20 April 2010

Academic Editor: Chung-Liang Chien

Copyright (C) 2010 T. Masaki and K. Matsumura. This is an open access article distributed under the Creative Commons Attribution License, which permits unrestricted use, distribution, and reproduction in any medium, provided the original work is properly cited.

\begin{abstract}
Dystroglycan is a central component of the dystrophin-glycoprotein complex (DGC) that links extracellular matrix with cytoskeleton, expressed in a variety of fetal and adult tissues. Dystroglycan plays diverse roles in development and homeostasis including basement membrane formation, epithelial morphogenesis, membrane stability, cell polarization, and cell migration. In this paper, we will focus on biological role of dystroglycan in Schwann cell function, especially myelination. First, we review the molecular architecture of DGC in Schwann cell abaxonal membrane. Then, we will review the loss-of-function studies using targeted mutagenesis, which have revealed biological functions of each component of DGC in Schwann cells. Based on these findings, roles of dystroglycan in Schwann cell function, in myelination in particular, and its implications in diseases will be discussed in detail. Finally, in view of the fact that understanding the role of dystroglycan in Schwann cells is just beginning, future perspectives will be discussed.
\end{abstract}

\section{Introduction}

Dystroglycan was originally isolated from skeletal muscle as one of dystrophin-associated proteins, and found to be a main component of the dystrophin-glycoprotein complex (DGC), a multimeric transmembrane protein complex [1, 2]. In skeletal muscle, $\alpha$ - and $\beta$-dystroglycan constitute a membrane-spanning complex and interact with various subsarcolemmal and transmembrane proteins and components of basement membrane. Thus, DGC provides the physical link between extracellular matrix and subsarcolemmal cytoskeleton, indicating its role in structural stability of sarcolemma during contraction and extension of skeletal muscles [3]. In fact, mutations in DGC components lead to progressive muscle fiber degeneration, causing various types of muscular dystrophies [4].

Dystroglycan is also expressed in many other cell types and it plays a variety of roles in nonmuscle tissues. It has been implicated in basal lamina development in mouse embryo [5], epithelial development [6], somitegenesis [7], cell polarization [8-10], carcinogenesis [11, 12], infective pathogen targeting [13-15], and development of the central nervous system (CNS) [16, 17].

In this paper, we review current understanding of dystroglycan function in Schwann cells such as ensheathment, myelination as well as maintenance of other Schwann cell structures, and the implications of these findings to peripheral nervous diseases. In broad sense, "myelination" may include entire developmental process of myelin formation from radial sorting of axons to membrane wrapping forming compact myelin as well as assembly of the nodes of Ranvier and growth of internodes, which are inextricably linked with each other [18]. However, in this paper, we will use "myelination" mainly in a rather narrow sense, as a membrane wrapping process forming compact myelin after radial sorting is completed. 


\section{Molecular Architecture of Dystrophin-Glycoprotein Complex (DGC) in Schwann Cells}

Molecular architecture of DGC in Schwann cells has been extensively studied by our group and others ([19-29], Figure 1). The biochemical analysis revealed the similarities of the fundamental molecular architecture of DGC between Schwann cells and muscle cells as well as several critical differences between them. In peripheral nerve, dystroglycan is mainly present in abaxonal membrane of both myelinating Schwann cells and nonmyelinating Schwann cells [19, 22, 24, 30,31 , while it is also expressed in perineurial cells as well as satellite cells of dorsal root ganglia [32]. As in skeletal muscle, dystroglycan in Schwann cells consists of two subunits ( $\alpha$ and $\beta$ ), which are translated from a single mRNA as a propeptide that is proteolytically cleaved into two noncovalently associated proteins $[2,19,33]$. In Schwann cells, $\alpha$-dystroglycan is known to bind to two of the extracellular ligands, laminin-2 $(\alpha 2 \beta 1 \gamma 1)$, major laminin isoform in Schwann cell basement membrane, and agrin [19, 21-23]. Each of these has laminin G (LG)-like domains that mediate their high-affinity $\mathrm{Ca}^{2+}$ dependent binding to $\alpha$-dystroglycan $[34,35]$. While small amount of laminin-8 $(\alpha 4 \beta 1 \gamma 1)$ is also present in mature Schwann cell basement membrane, LG domains of laminin8 showed only a low affinity for the $\alpha$-dystroglycan receptor [36]. Apparent molecular mass of $\alpha$-dystroglycan in Schwann cells is $120 \mathrm{kDa}$ [19], which is smaller than that of skeletal muscle $(156 \mathrm{kDa})$, probably due to the difference of tissuespecific O-glycosylation within the mucin domain [4]. While the removal of $\mathrm{N}$-linked glycans alters the molecular weight of $\alpha$-dystroglycan by only $4 \mathrm{kDa}$ [1], and does not effect on its activity as an extracellular matrix receptor [37], full deglycosylation of $\alpha$-dystroglycan results in the complete loss of ligand-binding activity [37]. Thus, the sugar chains on the mucin-like domain are supposed to mediate these interactions. Actually, structural analysis of the sialylated O-linked oligosaccharides of bovine peripheral nerve $\alpha$ dystroglycan revealed a high abundance of a novel Omannosyl-type oligosaccharide, Sia $\alpha 2-3 \mathrm{Gal} \beta 1-4 \mathrm{GlcNAc} \beta 1$ $2 \mathrm{Man}-\mathrm{Ser} / \mathrm{Thr}$ (where Sia is sialic acid), and this tetrasaccharide was involved in the interaction of the $\alpha$-dystroglycan with laminin [38]. In other cell types, there are evidences that $\alpha$-dystroglycan binds to laminin-1 via sugar moieties other than the tetrasaccharide [39], while this is not confirmed in Schwann cells. Also, it was reported that nonglyosylated Nterminal fragment of $\alpha$-dystroglycan bound to laminin-2/-4, laminin-1, fibronectin and fibrinogen [40].

On the other hand, $\alpha$-dystroglycan is noncovalently anchored to $\beta$-dystroglycan in the Schwann cell membrane. $\beta$-dystroglycan is a type I transmembrane protein with a single transmembrane domain and a 120 amino acid long Cterminal cytoplasmic tail. The cytoplasmic tail is anchored to the cytoskeletal proteins, Dp116, Schwann cell-specific isoform of dystrophin, and utrophin, an autosomal homolog of dystrophin $[19,20,24,26,41-43]$. $\beta$-dystroglycan is supposed to interact with cytoskeleton via interaction with these submembranous proteins [42], while direct interaction of $\beta$-dystroglycan with f-actin was also reported [44]. $\alpha 1$ - dystrobrevin and four syntrophin isoforms $(\alpha 1, \beta 1, \beta 2$, and $\gamma 2$ ), which interact with dystrophin and utrophin, are also expressed in Schwann cells [25, 29]. These proteins are crucial for the formation of DGC-associated signaling scaffolds in membrane of many cell types including Schwann cell abaxonal membrane [45]. As for binding between $\beta$ dystroglycan and Dp116, 15 C-terminal amino acids of the cytoplasmic domain of $\beta$-dystroglycan are involved in the high affinity binding of Dp116, while $26 \mathrm{~N}$-terminal amino acids of the cytoplasmic domain are also involved in the low affinity binding of Dp116 [24]. In Schwann cells, MMP2 and MMP9 are suggested to be involved in $\beta$ dystroglycan processing, and produce a $30 \mathrm{kDa}$ fragment of $\beta$-dystroglycan [46-49].

As other membrane protein members of DGC, $\beta-, \delta$, $\varepsilon$-, and $\zeta$-sarcoglycans are expressed in Schwann cells. The four isoforms of sarcoglycans in Schwann cells seem to form stable tetrameric sarcoglycan complex that associates with dystrogycan and Dp116 to constitute larger DGC complex, as in the case of skeletal muscle $[25,26,50]$. Also, sarcospan is expressed in Schwann cells as a member of DGC [25].

Recently Albrecht et al. [29] reported that molecular architecture of DGC is different between the two distinctive Schwann cell abaxonal membrane compartments, membrane covering Cajal cytoplasmic band and membrane directly apposed to myelin sheath (DRP2/periaxin rich plaque). In the former compartment, $\beta$-dystroglycan forms a complex with Dp116, utrophin, $\alpha 1$-dystrobrevin, $\alpha 1$-, $\beta 1-, \beta 2-$, and $\gamma$-syntrophins, and ABCA1 (traditional type, Figure 1(a)), and in the latter, $\beta$-dystroglycan forms a complex with L-Periaxin and DRP2 (Figure $1(\mathrm{~b})$ ), which was originally characterized by Sherman et al. $[27,51]$ and Court et al. [52]. Also, Occhi et al. found expression of DGC in node of Ranvier, and the DGC in node of Ranvier seems to be compatible with the traditional type, comprising Dp116 and utrophin, but not periaxin and DRP2 [28]. They also found that laminin-2 $(\alpha 2 \beta 1 \gamma 1)$ and laminin-10 $(\alpha 5 \beta 1 \gamma 1)$ are expressed in the nodal region [28].

Among these DGC components, only laminin-2 and periaxin do not depend on dystroglycan for their localization in Schwann cell abaxonal membrane [25]. Recently, a giant protein, AHNAK was reported to modify laminin binding capacity of Schwann cell abaxonal membrane probably via interaction with DGC [53], while precise molecular interaction between AHNAK and DGC remain to be elucidated.

\section{Loss-of-Function Studies for DGC Components}

Functions of DGC components including core components such as dystroglycans in Schwann cells were mainly revealed by loss-of-function studies in animals by targeting mutagenesis as well as gene mutation survey for human and mouse muscular dystrophies (Table 1). In particular, double knockout of two functionally related genes as well as Schwann cell-selective gene ablation system such as Cre/loxP contributed to these studies (Table 1). Therefore, the findings obtained from these studies will be described in detail. 


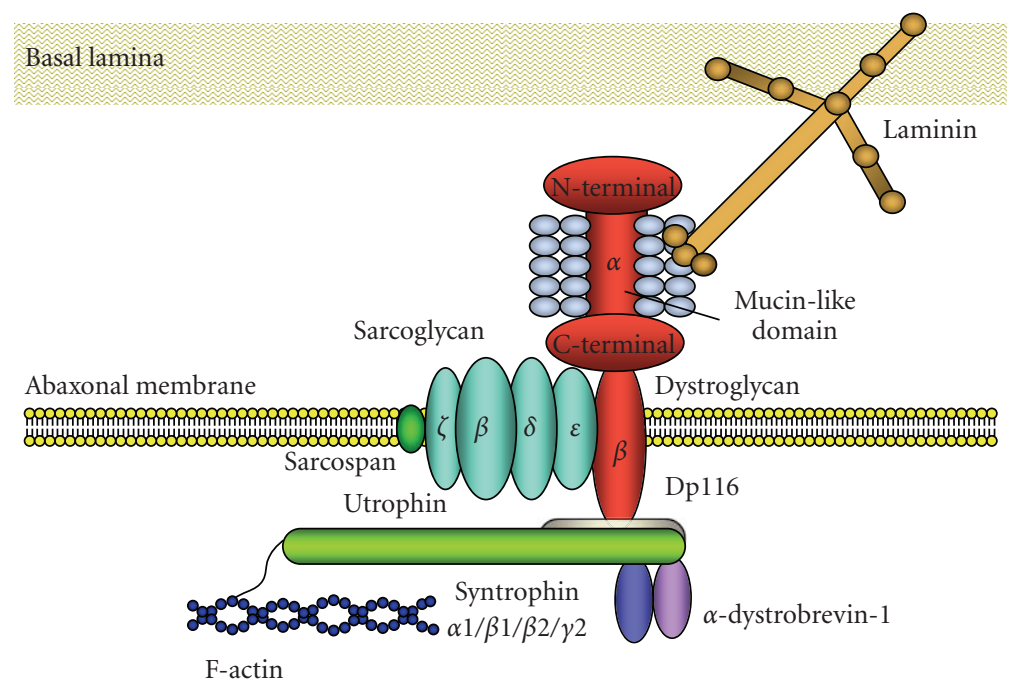

(a)

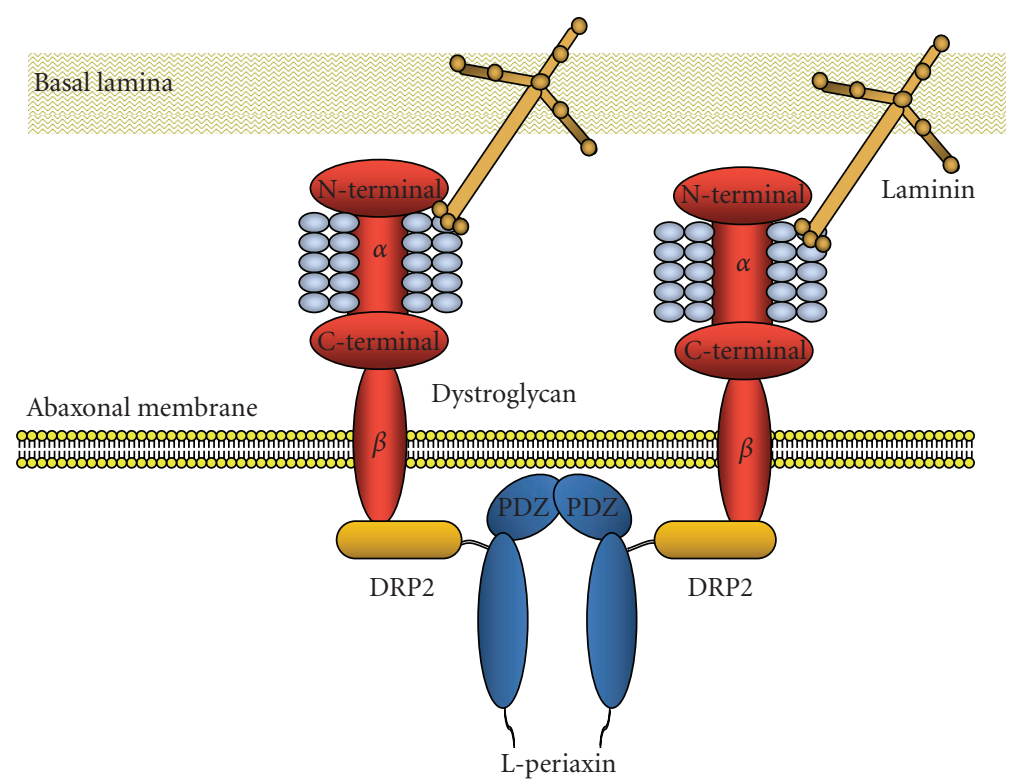

(b)

Figure 1: (a) Molecular structure of DGC (traditional type), present in Cajal cytoplasmic band of myelinated Schwann cells. a- and bdystroglycan form membrane-spanning complex in Schwann cell abaxonal membrane. Mucin-like domain of a-dystroglycan is involved in the interaction with laminin via laminin G-like domains. a-dystroglycan is noncovalently anchored to b-dystroglycan. The cytoplasmic tail of b-dystrogylcan is anchored to the cytoskeletal proteins, Dp116, Schwann cell-specific isoform of dystrophin, or utrophin, an autosomal homolog of dystrophin. Utrophin interact with f-actin at the N-teminus. Utrophin or Dp116 interacts with syntrophins (a1, b1, b2, g2) and a-dystrobrevin-1. Also at least four isoforms of sarcoglycan (b, d, e, z) form sarcoglycan complex in abaxonal membrane and interact with dystroglycan complex. Sarcospan is supposed to interact with sarcoglycan complex. Thus DGC provides the physical link between extracellular matrix and submembranous cytoskeleton in Schwann cells. (b) Molecular framework of DGC present in membrane portion directly apposed to myelin sheath (DRP2/periaxin rich plaque) of myelinated Schwann cells. In DRP2/periaxin rich plaques, dystroglycan complex intracellularly interact with DRP2, third member of dystrophin family, and periaxin, homodimeric PDZ domain-containing protein, via cytoplasmic domain of b-dystroglycan. This type of DGC lacks syntrophins and dystrobrevin.

3.1. Dystroglycan-Null Mice. The mutant mice showed a variety of morphological and functional abnormalities including redundant myelin loops, polyaxonal myelination at postnatal day 3-14, abnormal myelin sheath folding at 12 months, and axonal loss with aging [25]. The mice also showed nodal changes such as reduced sodium channel density, disorganized microvilli as well as axonal abnormalities in this region. However, because of the redundancy caused by other genes/proteins with similar biological functions such as $\alpha 6 \beta 4$ integrin, this loss-of-function study did not fully reveal 
TABle 1: Loss-of-function studies for DGC components.

\begin{tabular}{llll}
\hline $\begin{array}{l}\text { Disrupted genes } \\
(\text { animal })\end{array}$ & $\begin{array}{l}\text { Expression level and } \\
\text { modification of Schwann cell } \\
\text { proteins }\end{array}$ & Nerve pathology and functional deficits & References \\
\hline
\end{tabular}

Schwann cell-selective

Dag1 null mouse

(P0-DG null mouse)

Unknown (dy mouse)

Lama2/point

mutation of $\mathrm{LN}$

domain/CxxC motif (dy ${ }^{n m f 417}$ mouse)

Lama2/splicing skip of exon2 (dy2J

mouse)

Lama2 (dy3k mouse)

Lama4 (mouse)

Lama2/Lama4

(dy2J/ $\alpha 4$ null mouse)

Schwann cell selective Lamg1-null mouse

L-Periaxin (mouse)
No expression of DG

Reduced expressions of other DGC components except periaxin, laminin-2

No expression of laminin $\alpha 2$ Upregulation of laminin $\alpha 4$

Normal expression of the mutated laminin $\alpha 2$ chain

Normal expression of truncated laminin $\alpha 2$ chain (domain IV deleted)

Upregulation of laminin $\alpha 4$

No expression of laminin $\alpha 2$ Upregulation of laminin $\alpha 4$

No expression of laminin $\alpha 4$

Normal expression of truncated laminin $\alpha 2$ chain

No expression of laminin $\alpha 4$

Severely reduced expression of all known laminin isoforms in Schwann cells

No expression of L-periaxin
Mild radial sorting defect in spinal roots

Myelin folding/polyaxonal myelination

Mild loss of myelinated axons in sciatic nerve

Intact BM

Lower conduction

Disruption of nodes

Disrupted Cajal bands

Shortening of internodes

Radial sorting defect in nerve roots and cranial nerves

Mild radial sorting defect in peripheral nerves

Disrupted BM

Shortening of internodes

Lower conduction

Widened nodes of Ranvier

Radial sorting defect in nerve roots

Intact BM

Radial sorting defect in nerve roots and cranial nerves

Mild radial sorting defect in peripheral nerves

Multiple axons myelinated by one Sc

Disrupted BM

$52,55,57,60$

Disrupted Cajal bands

Shortening of internodes

A few solitary unmyelinated axons

Thin myelin sheath

Decreased nodal gap

Lower conduction

Disrupted BM

Radial sorting defect in peripheral nerves

Polyaxonal myelination

Intact BM

Severe radial sorting defect of peripheral nerves Mild radial sorting defect in spinal roots

Disrupted BM

Radial sorting defect in spinal roots and peripheral nerves

Demyelination in sciatic nerve

Myelin folding

Disrupted S-L incisure

Lower conduction

Impaired regeneration

Hyperalgesia, allodynia

Disrupted Cajal bands

Shortening of internodes 
Table 1: Continued.

\begin{tabular}{|c|c|c|c|}
\hline $\begin{array}{l}\text { Disrupted genes } \\
\text { (animal) }\end{array}$ & $\begin{array}{l}\text { Expression level and } \\
\text { modification of Schwann cell } \\
\text { proteins }\end{array}$ & Nerve pathology and functional deficits & References \\
\hline Utrophin (mouse) & No expression of utrophin & $\begin{array}{l}\text { Disrupted Cajal bands } \\
\text { Shortening of internodes }\end{array}$ & {$[52]$} \\
\hline $\begin{array}{l}\text { Sarcoglycans } \\
\text { (BIO14.6 hamster) }\end{array}$ & $\begin{array}{l}\text { No expression of sarcoglycans } \\
\text { Reduced expression of } \alpha \text {-DG and } \\
\text { Dp116 }\end{array}$ & $\begin{array}{l}\text { Myelin folding } \\
\text { Disrupted S-L incisure }\end{array}$ & {$[50]$} \\
\hline $\begin{array}{l}\text { Large null mouse } \\
\text { (enr, myd) }\end{array}$ & $\begin{array}{l}\text { Very low expression of Large } \\
\text { Hypoglycosylation of } \alpha \text {-DG }\end{array}$ & $\begin{array}{l}\text { Radial sorting defect in sciatic nerve and spinal } \\
\text { roots } \\
\text { Intact BM } \\
\text { Lower conduction } \\
\text { Disrupted Cajal bands } \\
\text { Impaired regeneration }\end{array}$ & {$[52,70]$} \\
\hline $\begin{array}{l}\text { Fukutin chimera } \\
\text { mouse }\end{array}$ & $\begin{array}{l}\text { Deficiency of fukutin } \\
\text { Hypoglycosylation of } \alpha \text {-DG }\end{array}$ & $\begin{array}{l}\text { Radial sorting defect in sciatic nerve and spinal } \\
\text { roots } \\
\text { Loss of myelinated axons in nerve roots and } \\
\text { sciatic nerve at P15-30 } \\
\text { Multiple axons myelinated by one Sc } \\
\text { Intact BM } \\
\text { Disruption of NMJ }\end{array}$ & {$[71]$} \\
\hline $\begin{array}{l}\text { Schwann cell-selective } \\
\beta 1 \text { integrin null } \\
\text { mouse }\end{array}$ & No expression of $\beta 1$ integrin & $\begin{array}{l}\text { Radial sorting defect in sciatic nerve } \\
\text { Disrupted BM }\end{array}$ & {$[72]$} \\
\hline $\begin{array}{l}\text { Schwann cell-selective } \\
\beta 4 \text { integrin null } \\
\text { mouse }\end{array}$ & No expression of $\beta 4$ integrin & Myelin folding & {$[54]$} \\
\hline $\begin{array}{l}\text { Schwann cell-selective } \\
\beta 4 \text { integrin/Dag1 null } \\
\text { mouse }\end{array}$ & $\begin{array}{l}\text { No expression of DG and } \beta 4 \\
\text { integrin }\end{array}$ & $\begin{array}{l}\text { Radial sorting defect in spinal ventral roots } \\
\text { Severe myelin folding } \\
\text { Demyelination } \\
\text { Disrupted BM }\end{array}$ & {$[54]$} \\
\hline
\end{tabular}

BM: basement membrane, DG: dystroglycan, S-L: Schmidt-Lanterman, NMJ: neuromuscular junction, Sc: Schwann cell.

the roles of dystroglycan in Schwann cell function including myelination, which will be discussed in detail later.

3.2. Laminin $\alpha$ Chain-Null Mice. As typically observed in dy/dy mice and dy2J/dy2J mice, loss of laminin $\alpha 2$ chain expression in mice constantly resulted in not only congenital muscular dystrophy but also radial sorting defect in peripheral nerve characterized by the presence of bundles of naked axons (unmyelinated axons) more evident in the proximal part of the PNS [55-60, 62-64, 67]. Moreover, transgenic rescue of laminin defect in muscle of dy/dy mice revealed that the neuropathy significantly contributes to the disease phenotype [73]. Recently, Yu et al. [65] reported that laminin is necessary for Schwann cell morphogenesis, especially during radial sorting, and suggest that laminin signaling is a central regulator coordinating the processes of proliferation and morphogenesis in radial sorting.
In the spinal roots of laminin $\alpha 2$ chain-deficient mice, expression of laminin $\alpha 4$ chain was increased and expression of laminin $\alpha 5$ chain was preserved [61, 66, 67]. Interestingly, loss of laminin $\alpha 4$ chain showed bundles of naked axons more evident in distal part of the PNS [67]. Double knockout of $\alpha 2$ and $\alpha 4$ chains led to most numerous naked axons in tibial nerve, but paradoxically improved the radial sorting in spinal root [67]. Also, transgenic laminin $\alpha 5$ chain expression promoted myelination [67]. Laminin $\alpha 1$ chain is also suggested to compensate the deficiency of laminin $\alpha 2$ chain, and actually transgenic expression of laminin $\alpha 1$ chain rescued radial sorting defect of spinal roots of dy $3 \mathrm{~K} / \mathrm{dy} 3 \mathrm{~K}$ mice $[74,75]$. In addition, inactivation of all known laminin isoforms in Schwann cells led to radial sorting defect in both spinal roots and sciatic nerve [68]. These results indicated the complicated functional redundancy of the four kinds of laminin $\alpha$ chain isoforms $(\alpha 1, \alpha 2, \alpha 4$, and $\alpha 5)$, or even other unrecognized proteins with similar function. 
Another important finding in dy mice is the abnormal sodium channel clusters in nodes of Ranvier [28], which was identical in quality but less severe than those observed in dystroglycan-null mice [25]. This nodal abnormality was supposed to be caused by laminin-2 deficiency because laminin-2 and laminin-10 are expressed in normal nodes and paranodes [28]. Notably, laminin- $\alpha 1$ chain was upregulated in dy mice nodes [28].

3.3. Integrin-Null Mice. While integrin is not supposed to be a member of DGC, $\alpha 6 \beta 4$ and $\alpha 6 \beta 1$ integrins are another important laminin receptors in Schwann cells, and have been suggested to be involved in Schwann cell myelination [7678]. Dissecting functions of those integrins is critical for delineating exact role of dystroglycan, and therefore, the studies for integrin-null mice will be reviewed in this paper.

Schwann cell specific disruption of $\beta 1$ integrin showed large bundle of naked axons in both spinal roots and sciatic nerves suggesting severe impairment of radial sorting process [72]. Notably, myelinated Schwann cells never expressed $\beta 1$ integrin, suggesting that $\beta 1$ integrin is not always necessary for myelination process once Schwann cells have achieved $1: 1$ relationship with large axons [72].

In contrast, Schwann cell specific disruption of $\beta 4$ integrin did not affect peripheral nerve development, myelin formation, maturation, or regeneration except abnormal myelin folding with ageing [54]. However, disruption of both $\beta 4$ integrin and dystroglycan showed severer hypomyelination in spinal roots than dystroglycan-null mice, with acute sign of demyelination such as myelin degeneration, macrophage infiltration and remyelination [54]. It also showed major folding abnormalities in sciatic nerve myelin, suggesting a role of dystroglycan in myelin stabilization with the cooperation of $\beta 4$ integrin.

3.4. Mice with $\alpha$-Dystroglycan Glycosylation Defects. Recent advances have highlighted the importance of $\alpha$-dystroglycan glycosylation in dystroglycan functions. Actually, mutation in the genes encoding LARGE, POMGnT1, POMT and fukutin cause defects in $\alpha$-dystroglycan glycosylation, and altered capacity for binding to laminin, agrin, and neurexin $[79,80]$. As a result, the glycosylation defects lead to the human disorders, congenital muscular dystrophy 1D (MDC1D), muscle-eye-brain disease (MEB), Walker-Warburg disease (WWS), and Fukuyama congenital muscular dystrophy (FCMD), which are collectively called $\alpha$-dystroglycanopathy [81-83]. Because defects in $\alpha$-dystroglycan glycosylation should reduce the laminin-2 binding capacity of $\alpha$-dystroglycan in not only muscle cells but also Schwann cells, Schwann cell functions associated with dystroglycan-laminin-2 interaction should be impaired in $\alpha$-dystroglycanopathy. However, peripheral nerve involvement in $\alpha$-dysroglycanopathy has not been extensively studied. Therefore, we embarked on the investigation whether peripheral nerve development, especially myelination, is defective or not in fukutin-deficient chimeric mice, a mouse model of FCMD [71]. As a result, we demonstrated that the sugar chain moiety and laminin-binding activity of $\alpha$ dystroglycan were severely reduced, while the expression level of laminin-2 seemed to be unaffected. The fukutin chimeric mice showed cluster of naked axons and loss of myelinated fibers in both sciatic nerve and spinal roots at P30. After 20 months of age, some spinal roots showed striking loss of myelinated axons as well as degenerated axons suggesting the progressive neuropathy with aging. Also, occasionally multiple axons were myelinated by single Schwann cell, which was also found in dy2J/dy2J mice [59]. These results suggest that $\alpha$-dystroglycan glycosylation plays roles in Schwann cell differentiation including ensheathment and myelination, as well as maintenance of myelin in adult mice [71].

Similar to fukutin chimeric mice, Large-null mice (enr and myd mice) showed cluster of naked axons in sciatic nerve, while the sodium channel clustering in nodes of Ranvier was unaffected [70].

Altogether, Schwann cell myelination is disturbed in $\alpha$-dystroglycanopathy mice. Therefore, scrutinization of peripheral nerve involvement in human $\alpha$-dystroglycanopathy will reveal more detailed characterization of those diseases.

3.5. Periaxin-Null Mice. Studies of periaxin-null mice revealed a unique aspect of DGC biological function in Schwann cells. Periaxin-null mice did not show defect in peripheral nerve development, instead they showed progressive demyelination as well as abnormal myelin sheath foldings in sciatic nerve, suggesting unstable myelin sheath [69]. Also periaxin-null mice showed abnormal Schwann cell compartmentalization, disruption of protoplasmic bands of Cajal, and impaired Schwann cell internodal growth [51, 52]. Recently, Court et al. [52] demonstrated that laminin2 , dystroglycan, utrophin axis is also required for proper Schwann cell compartmentalization, and correct internodal length.

3.6. Sarcoglycan-Null Hamster. Sarcoglycan-null hamster (BIO14.6) showed that $\delta$-sarcoglycan induced agedependent myelin disruption or abnormal foldings and perturbed Schmidt-Lanterman incisures [50]. Together with loss of sarcoglycan complex and reduced expression of $\alpha$-dystroglycan and Dp116, these findings suggested that sarcoglycans in Schwann cells stabilize DGC-mediated transmembrane extracellular matrix-cytoskeleton linkage, and thus play a role in myelin stability.

\section{Detailed Role of Dystroglycan in Schwann Cell Function}

Based on the findings derived from loss-of-function studies described above and other previous studies, detailed role of dystroglycan in Schwann cell function will be discussed in detail in this section.

4.1. Role of Dystroglycan in Myelination and Myelin Maintenance. It is well known that basement membrane plays an important role in Schwann cell ensheathment and myelination $[84,85]$. Therefore, the discovery in early 1990 s that congenital muscular dystrophy as well as dysmyelination 
of nerve roots in dy/dy mice are due to lack of laminin2 prompted us to investigate whether dystroglycan, a high affinity receptor for laminin-2, plays a role in myelination [86].

In order to address this issue, we analyzed Schwann cell expression of $\beta$-dystroglycan and laminin $\alpha 2$ chain during rat peripheral nerve regeneration and development. As a result, $\beta$-dystroglycan protein was present most densely in early myelinating Schwann cells, intermediately in promyelinating Schwann cells, and most faintly in the Schwann cells in the transient stage between immature Schwann cells and promyelinating Schwann cells in rats at the age of P3 [87]. Another group also reported that $\beta$-dystroglycan appear as a protein peinataly, just before myelination, exclusively in outer surface of mouse Schwann cells [74], which was consistant with our results derived from rat peripheral nerves. Also, the expression of $\beta$-dystroglycan protein dramatically increased during first week after birth of rats, and was maintained until adulthood. The expression of laminin $\alpha 2$ chain also increased during the first week, and continued to increase until adulthood [87]. The expression of $\beta$ dystroglycan was down-regulated by axonal degeneration in adult rats, and was induced again by axon contact during axonal regeneration [30]. These results indicate that dystroglycan is associated with myelination as well as myelin maintenance rather than radial sorting. Second, Schwann cell-specific dystroglycan-null mice showed abnormally thin myelinated fibers as well as abnormal myelin folding in which Schwann cell established 1:1 relationship with axon, suggesting that dystroglycan plays a role in myelination after radial sorting is completed $[25,54]$. Also the dystroglycannull mice showed mild loss of myelinated axons with aging. Third, double knockout of $\beta 4$ integrin and dystroglycan revealed far severer hypomyelination than respective knockout of each of the two genes, as well as signs of acute demyelination [54]. Notably the hypomyelination caused by disruption of dystroglycan was most severe in spinal ventral roots [54]. Fourth, fukutin chimeric mice and Largenull mice showed hypomyelination as well as signs of progressive demyelinating neuropathy $[70,71]$. Considering these evidences, dystroglycan no doubt plays a role in myelination as well as in myelin maintenance.

While $\alpha 6 \beta 4$ integrin was also suggested to play a role in myelination and myelin maintenance $[76,78]$, single disruption of $\beta 4$ integrin unexpectedly did not show any abnormalities of peripheral nerve myelin except age-dependent myelin folding [54]. However double knockout of dystroglycan and $\beta 4$ integrin described above showed cooperative role of $\beta 4$ integrin with dystroglycan in myelination and myelin maintenance [54].

It is interesting to note that $\alpha$-dystroglycan serves as a receptor for several pathogens such as Mycobacterium leprae (M.leprae), lymphocytic choriomeningitis virus and the Lassa fever virus [13-15, 88-90]. In particular, M.leprae cause acute nonimmune-mediated demyelination in mouse peripheral nerve [91], and the demyelination is at least partly mediated by ErbB2 receptor tyrosine kinase signaling [92]. However, it remains to be elucidated whether M.leprae cause demyelination via perturbation of dystroglycan function as well as whether dystroglycan has some interaction with the ErbB2 signaling, while it was reported that Lassa fever virus efficiently competes with laminin $\alpha 1$ and $\alpha 2$ chains for $\alpha$ dystroglycan binding [90].

Dystroglycan is also expressed in oligodendrocyte as a laminin receptor along with $\beta 1$ integrins, and may play a role in myelination by oligodendrocyte [93]. This study offered new insight into $\alpha$-dystroglycanopathies that cause brain dysmyelination, as well as into the mechanism that underlies CNS myelin abnormalities caused by laminin deficiencies [93]. While structural myelin abnormalities are usually not very clear in CNS of laminin deficient human and mice [94], meticulous quantitative and morphological analysis suggested the presence of defects of CNS myelin in dy/dy mice, in particular in small-sized axons [95].

4.2. Role of Dystroglycan in Radial Sorting. It was unclear whether dystroglycan played a role in radial sorting process from the loss-of-function studies of dystroglycan [25]. However the possibility cannot be denied because radial sorting defect in spinal roots was observed in both Largenull mice and fukutin chimeric mice [70, 71]. This suggests glycosylation of $\alpha$-dystroglycan may be necessary for radial sorting, although the possibility that unidentified substrate proteins of these glycosylating enzymes play a role in radial sorting cannot be denied.

On the other hand, $\beta 1$ integrin null mice showed a major abnormality in radial sorting [72]. $\beta 1$ integrin binds to LG domains of laminin-2 different from $\alpha$-dystroglycan binding sites. Taken together, there is still a possibility that dystroglycan may cooperate with $\beta 1$ integrin in radial sorting process.

4.3. Role of Dystroglycan in Development and Maintenance of Schwann Cell Structures such as Cajal Cytoplasmic Band, Internode and Node of Ranvier. The loss-of-function studies provided evidences that dystroglycan plays roles in development and maintenance of Schwann cell structures such as Cajal cytoplasmic band, internode and node of Ranvier. First, Schwann cell-specific dystroglycan null mice showed nodal changes including reduced sodium channel density and disorganized microvilli $[25,28]$. Second, dystroglycan along with periaxin, utrophin and laminin-2, is necessary for compartmentalization including Cajal cytoplasmic band formation and elongation of myelin segments [52]. These studies offered new aspects of dystroglycan function in Schwann cells, and will stimulate further studies of DGC concerning internode growth as well as nodal functions.

\section{Molecular Mechanisms of Dystroglycan in Schwann Cell Myelin Formation}

Molecular mechanisms of how dystroglycan regulates Schwann cell myelination remain to be elucidated. One possibility is that the link between dystroglycan and laminin2 provide anchorage between Schwann cell abaxonal membrane and basal lamina on which progression of inner lip of Schwann cells over the axonal surface is based during myelin 
formation [96]. Evidences that dystroglycan has binding capacities between Schwann cell abaxonal membrane and basement membrane or laminin support this idea $[25,97$, 98]. Notably, basement membrane is not always necessary for myelination $[60,99]$. Probably it is just because less organized extracellular matrix components, which are not visible as electron dense basement membrane, are enough for myelination. In support of this idea, Podratz et al. [99] showed abundant laminin deposition on Schwann cell abaxonal surface in spite of the lack of visible basement membrane.

Another possibility is that dystroglycan plays a role in myelination by regulating signaling from extracellular matrix, especially laminin-2, to intracellular signaling pathways or cytoskeleton. Actually, laminin signaling seems to play an essential role in Schwann cell proliferation and survival as well as cytoskeletal regulation-associated ensheathment and myelination $[60,100]$. While dystroglycan is a major laminin receptor in Schwann cells along with integrins such as $\alpha 6 \beta 1, \alpha 6 \beta 4$, and $\alpha 7 \beta 1$, the receptor function of dystroglycan mediating laminin signaling has been less extensively studied compared with that of integrins. Recently, however, ample evidences are accumulating that dystroglycan is associated with cell signaling.

First, $\beta$-dystroglycan can interact with a variety of signaling proteins, at least partly via $\mathrm{SH} 2$ and $\mathrm{SH} 3$ binding sites in the $\mathrm{C}$-terminus. While dephosphorylation of Y892 (pY892) in $\beta$-dystroglycan enables binding to utrophin/dystrophin[101, 102], phosphorylation of $\beta$ dystroglycan enhances recruitment of $\mathrm{SH} 2 / \mathrm{SH} 3$ domain containing signaling-associated proteins like c-Src, Fyn, Csk, Nck, Shc, and Grb-2 [103-106]. Grb-2 is known to be involved in ERK-MAP kinase cascade and cytoskeletal organization [103]. Also $\beta$-dystroglycan can interact with FAK [104]. In addition, DAMAGE was reported to be a new member of DGC as a protein associated with $\alpha$-dytrobrevin [43]. DAMAGE has a potential nuclear localization signal, 30 contiguous 12-aminoacid repeats and two MAGE homology domains, suggesting it is involved in membrane signaling [43].

Moreover, in nonperipheral nerve tissues, dystroglycan has been shown to be involved in several signaling pathways. Association of dystroglycan with MAPK/ERK cascade and GTPase signaling was reported [107-109]. Filopodia formation is often governed by Cdc42, a GTPase signalingassociated protein playing diverse roles in cell polarity, cytoskeletal regulation as well as cell cycle [109]. Dystroglycan plays a role in filopodia formation via forming a complex with ezrin and Dbl, and activating Cdc42 [107109]. Fibronectin or biglycan may induce signaling via dystroglycan leading to calcium flux and alteration of cytoskeletal architecture [110]. Syntrophin contains two pleckstrin homology $(\mathrm{PH})$ domains and one PDZ domain [111]. Binding of laminin to DGC induced heterotrimeric G protein binding to $\alpha$-syntrophin's PDZ domain, which leads to activation of PI3K/Act signaling and alteration of intracellular $\mathrm{Ca}^{2+}$ in muscle [111-114]. Laminin-1 induced Grb binding to syntrophin, recruited Sos1/Rac1/PAK1/JNK, and eventually led to c-jun phosphorylation [115]. Recently, genetic modifier screens using Drosophila melanogaster revealed that DGC interacts with genes involved in Notch, TGF- $\beta$ and EGFR signaling pathways as well as those associated with muscle function and cellular or axonal migration [116]. In Schwann cells also, laminin assembly initiated dystroglycan-dependent Src/Fyn activation and utrophin recruitment that contributed to their survival [117]. Taken together, these evidences strongly suggest that dystroglycan signaling plays diverse roles in Schwann cell functions including myelination. The hypothetical role of dystroglycan signaling in Schwann cell myelination will be discussed in detail in the section of future perspectives.

\section{Human Peripheral Nervous System (PNS) Diseases Associated with DGC}

Among the human diseases caused by mutation of DGC components, there are only two diseases in which peripheral nerve involvement was clearly demonstrated, MDC1A (LAMA2 mutation) and neuropathy caused by PRX mutation, which will be described in detail below. In general, peripheral nerve involvement caused by mutation of DGC components has not been studied as extensively as muscular dystrophies. Therefore, there is still a possibility that further study in the future will reveal new evidences that other DGC components play roles in the pathogenesis of human peripheral neuropathies.

\subsection{MDC1A (Merosin (Laminin-2)-Deficient Congenital} Muscular Dystrophy). MDC1A is the most frequent congenital muscular dystrophy in Europe with autosomal recessive inheritance caused by LAMA2 mutation [94, 118]. Complete laminin-2 deficiency causes early-onset muscular dystrophy, peripheral neuropathy and white matter lesions in CNS. Partial laminin-2 deficiency presents variant phenotypes with later onset muscular dystrophy, or even predominant PNS or CNS abnormalities. While peripheral nerve involvement is not extensively studied in MDC1A, nerve conduction velocity is reduced in most of the patients [119-123]. As a basis for the slowed conduction velocity, abnormal sodium channel clusters were found in these patients [28]. The neuropathy is predominantly motor or sensory-motor [120123]. Sural nerve biopsy showed mild loss of myelinated fibers, globular thickening of myelin sheath at paranodal region, myelin foldings, shortened internodes, widened nodes of Ranvier [121, 124], and compartmentalization defects [52]. Unfortunately, radial sorting defect in spinal roots in human has not been confirmed because of the absence of autopsy study.

Patients with MDC1A show striking white matter changes in T2 weighted brain magnetic resonance imaging [125], which is diffuse, bilateral, and symmetrical. It appears after the first 6 months of life, and nonprogressive [126]. However, morphological changes of cerebral white matter are not clearly demonstrated in human patients. Rather, main pathological findings in CNS are developmental anomalies such as abnormal cerebral cortical gyration, hypoplasia of vermis, hemisphere, or pons. At least, part of these abnormalities is supposed to be caused by neuronal migration 
defects associated with laminin-2- $\alpha$-dystroglycan interaction, which are also demonstrated in $\alpha$-dystroglycanopathies. The full aspects of dystroglycan roles in CNS are beyond the scope of this review, and other comprehensive reviews deal in detail with these issues $[81,127-130]$.

6.2. Charcot-Marie-Tooth Neuropathy Type 4F and Dejerine Sottas Neuropathy Caused by PRX (Periaxin) Mutations. Periaxin is the only one gene of members of DGC reported to be associated with human hereditary demyelinating neuropathy. Mutation of PRX causing loss of L-periaxin expression induces sensory-motor demyelinating neuropathy consistent with Charcot-Marie-Tooth neuropathy or Dejerine Sottas neuropathy [131-133]. Homozygous PRX mutation C715X causing expression of truncated form of L-periaxin showed relatively milder phenotype of CharcotMarie-Tooth neuropathy with sensory dominant involvement [134]. Nerve biopsy showed loss of myelinated fibers, onion bulbs, focal thickening of myelin sheath, and myelin folding, which were similar to the nerve pathology of Prx-/mice [131-134].

\section{Future Perspectives}

Schwann cell is one of the somatic cell types with robust regenerative capacity. The regenerative capacity of Schwann cell depends on its property of plasticity, which enables Schwann cell to change its phenotype between differentiated Schwann cell (myelinating type and nonmyelinating type) and denervated (dedifferentiated) Schwann cell [135, 136]. Recent advances have highlighted the importance of gene/protein network maintaining the identity of cell phenotype, especially from the study of embryonic stem cells $[137,138]$. Then, there must be molecular network specific to each of the Schwann cell phenotypes. Definitely dystroglycan and other DGC components belong to the molecular network specific to myelinating Schwann cell phenotype, and now it is important to understand the role of dystroglycan in the context how this protein contributes to the gene/protein network. Cutting edge technologies such as DNA microarray, ultra-high-throughput sequencing and mass spectroscopy-based proteomics have made it possible to study epigenome, transcriptome, and proteome as a whole [137, 139]. Analyzing gene/protein network maintaining identity of myelinating Schwann cell phenotype, and comparing with that of dedifferentiated Schwann cell phenotype will reveal a whole framework of molecular mechanisms of myelination.

At the same time, it is important to study dystroglycan function focusing on specific molecular aspects such as protein interaction, signaling, transcriptional regulation including chromatin modifications, post-transcriptional modification, post-translational modification, and intracellular transport and degradation. In addition, anatomical aspects should be taken into consideration. Myelinating Schwann cell has four distint domains: internode, juxtaparanode, paranode, and node [140, 141]. Moreover, internode domain is divided into two compartments; Cajal cytoplasmic band, and compartment occupied by myelin sheath [51]. Each domain is playing a specific role in maintaining myelinating Schwann cells, and DGC is likely to play different role in each of the domain. In many of these specific aspects, dystroglycan function is just beginning to be revealed, and so many questions must be answered. A few of the mutually nonexclusive topics with high priority will be discussed below.

(1) Protein Interaction. various proteins have been and are beginning to be revealed to interact with DGC in nonperipheral nerve tissues. Examples are extracellular matrix proteins such as fibronectin/biglycan $[110,142]$, perlecan [143-145], pikachurin [146], membrane proteins/receptors such as integrins [147, 148], AHNAK [53], aquaporins [149, 150], MLC1 [151], caveolins [147], Na and K channels [141, $149,152-154]$, and submembranous or cytoskeletal proteins such as $G$ proteins or other signaling-associated proteins $[103,106,111,113,115]$, nitric-oxide synthase [147], actins [43], tubulins [155], ERMs (ezrin-radixin-moesin) [108, 109], and Par1 [10]. Dissecting their interactions with DGC in Schwann cells one by one will reveal more comprehensive molecular architecture, and specific functions associated with it.

(2) Signaling. Myelinating Schwann cell phenotype is supposed to be maintained by signaling from both abaxonal membrane contacting extracellular matrix and adaxonal membrane apposing to axon. And the integrated signaling from both directions is supposed to maintain transcriptome or cytoskeletal structures specific to myelinating Schwann cells. Dystroglycan may play a role in signaling from abaxonal membrane via the interaction with other proteins present in extracellular matrix /abaxonal membrane/cytoskeleton, especially with laminin-2 and $\alpha 6 \beta 4$ integrin. Then dystroglycan-associated signaling is supposed to activate positive regulators of myelination, and inactivate negative regulators of myelination. Evidences accumulated by studies of nonperipheral nerve tissues suggest a number of hypotheses in this issue. As examples, several hypotheses will be described below.

First is about the association of dystroglycan or syntrophin with signaling-associated proteins such as Src, Fyn, Csk, Nck, Shc, and Grb2 [103-106, 108, 109, 115]. Interaction of DGC with these adaptor proteins implies that DGC may regulate Rho family GTPase signaling as well as MAPK signaling cascade [103-106, 108, 109, 115, 156]. Or yeast two hybrid screens suggested that dystroglycan can directly activate MEK or ERK, members of MAPK cascade [107]. Because it was reported that Ras signaling promotes differentiation of Schwann cells [157], dystroglycan may promote myelination through Ras signaling. However, it is controversial whether Ras/Raf/ERK signaling is promoting Schwann cell differentiation because there is a report that Ras/Raf/ERK signaling drives Schwann cell dedifferentiation [158]. On the other hand, Cdc42, one of the Rho family GTPases, was suggested to promote radial sorting and myelination [65]. So Cdc42 may be another mediator of dystroglycan signaling.

Second, genetic modifier screens suggested the association of dystroglycan with Notch signaling [116]. In Schwann 
cells, Notch acts as a negative regulator of myelination [135, 159]. Dystroglycan, therefore, can promote myelination via regulating Notch signaling. Notably, Notch signaling and WNT signaling seem to prevent oligodendrocyte differentiation (myelination). Notch signaling and WNT signaling respectively can induce HES5 and ID2/4, repressors of myelin genes, via transcription factor activity of NICD (Notch1 intracellular domain)/CBF1 and $\beta$-catenin/TCF7L2, and then HES5 or ID2/4 represses the transcription of myelin genes [160, 161]. Moreover, HDACs (histone deacetylases) can relieve these repressions by competing with the NICD to bind to $\mathrm{CBF} 1$ and competing with $\beta$-catenin to bind to TCF7L2. At the same time, the HDACs might increase the state of chromatin compaction around genes such as HES5, ID2, and ID4 that encode repressors of oligodendrocyte differentiation, thus preventing their transcription and providing permissive conditions for oligodendrocyte differentiation $[160,161]$.

Third, Krox20, one of the key myelin-associated transcription factors [162], might be another candidate mediator of dystroglycan signaling, because laminin signaling increases Krox-20 expression [163]. Krox 20 can inhibit c-Jun activity [164]. Also Krox 20 can suppress Notch signaling by reducing NICD post-translationally [159].

Fourth, DGC can interact with FAK [104]. FAK is an ECM-associated signaling protein and is at the crossroad of multiple signaling pathways, interacting with Rho GTPase signaling as well as MAPK signaling [165]. Effects of FAK on cytoskeletal organization were well demonstrated [165]. Moreover, FAK was recently reported to be required for radial sorting [166]. FAK can interact also with Erb2/Erb3 receptor [167], and then Erb2/Erb3 receptor can promote myelination [100]. Notably, laminin deficiency caused dramatic decrease of Erb2/Erb3 receptor phosphorylation [100]. Therefore, DGC may regulate radial sorting or myelination via interaction with FAK.

(3) Transcriptional Regulation. little is known about transcriptional regulation of dystroglycan or other DGC components in Schwann cells. Recently, Rettino et al. [168] reported that the expression of dystroglycan was regulated by SP1 transcription factor in muscle cells, and DNA methylation as well as histone acetylation may be involved in the regulation. In addition, Miura et al. [169] reported that $\operatorname{PPAR} \beta / \delta$ agonist stimulated the transcription of utrophin, which restored the expression of $\alpha 1$ syntrophin and $\beta$ dystroglycan at the sarcolemma of the mdx mice. However, so many issues still remain to be answered considering the extremely complicated mechanisms of transcriptional regulation exerted by various transcriptional regulators as well as chromatin modifications including DNA methylation and all kinds of histone modifications [170].

(4) Node of Ranvier. While dystroglycan-null mice showed variety of nodal abnormalities including disorganized microvilli and reduced sodium channel density, the molecular mechanism remains to be unknown. In order to address this issue, it will be important to study the interaction of dystroglycan with node-associated proteins. For example, ERMs are expressed in the microvilli of many cell types including those of Schwann cells [171]. In nonperipheral nervous tissues, it is known that dystroglycan plays a role in filopodia formation via interaction with ezrin, and subsequent activation of Cdc42 [108, 109]. Then Cdc42 is supposed to induce cytoskeletal changes necessary for filopodia formation [108, 109]. Therefore, dystroglycan may be associated with Schwann cell microvilli formation through interaction with ERMs.

(5) Cell Polarity. While Schwann cells do not belong to epithelial cells, Schwann cells have many molecular and structural properties similar to epithelial cells $[140,172]$. In particular, cell polarity is a central feature shared by Schwann cells with epithelial cells $[140,172]$. Several lines of evidences suggest that dystroglycan plays a role in maintaining cell polarity of not only epithelial cells but also Schwann cells [810, 30, 172]. First, in Wallerian degeneration, Schwann cell phenotype changes from myelinating type to dedifferentiated type [135]. During this process, the cell polarity specific to myelinating Schwann cells is lost along with the dissociation of basement membrane from abaxonal membrane as well as downregulation of dystroglycan and laminin2 [30]. This finding suggests that dystroglycan-laminin2 interaction is involved in cell polarity maintenance of myelinating Schwann cells. Second, Cdc42, which seems to have several links with dystroglycan signaling, is one of the cental regulators of cell polarity in epithelial cells as well as glial cells [172]. Third, cell polarity protein Par-1 not only regulates the basolateral localization of DGC, but also is required for the formation of a functional DGC in epithelial cells [10]. Analyzing molecular interactions of DGC with cell polarity-associated proteins will reveal further detailed function of dystroglycan.

\section{Conclusion}

Dystroglycan plays diverse roles in Schwann cells such as myelination and maintenance of myelin and nodal structures. However, the molecular mechanisms on which dystroglycan functions are based are just beginning to be revealed. Analyzing gene/protein network as a whole system using cutting edge technologies as well as individual studies focusing on a variety of biological aspects specific to Schwann cells hold promise for elucidating molecular mechanism of dystroglycan functions, and eventual development of effective treatments for human peripheral neuropathies.

\section{References}

[1] J. M. Ervasti and K. P. Campbell, "Membrane organization of the dystrophin-glycoprotein complex," Cell, vol. 66, no. 6, pp. 1121-1131, 1991.

[2] O. Ibraghimov-Beskrovnaya, J. M. Ervasti, C. J. Leveille, C. A. Slaughter, S. W. Sernett, and K. P. Campbell, "Primary structure of dystrophin-associated glycoproteins linking dystrophin to the extracellular matrix," Nature, vol. 355, no. 6362, pp. 696-702, 1992.

[3] B. J. Petrof, J. B. Shrager, H. H. Stedman, A. M. Kelly, and H. L. Sweeney, "Dystrophin protects the sarcolemma from stresses developed during muscle contraction," Proceedings 
of the National Academy of Sciences of the United States of America, vol. 90, no. 8, pp. 3710-3714, 1993.

[4] R. Barresi and K. P. Campbell, "Dystroglycan: from biosynthesis to pathogenesis of human disease," Journal of Cell Science, vol. 119, no. 2, pp. 199-207, 2006.

[5] R. A. Williamson, M. D. Henry, K. J. Daniels, R. F. Hrstka, J. C. Lee, Y. Sunada, O. Ibraghimov-Beskrovnaya, and K. P. Campbell, "Dystroglycan is essential for early embryonic development: disruption of Reichert's membrane in Dag1null mice," Human Molecular Genetics, vol. 6, no. 6, pp. 831841, 1997.

[6] M. Durbeej, E. Larsson, O. Ibraghimov-Beskrovnaya, S. L. Roberds, K. P. Campbell, and P. Ekblom, "Non-muscle $\alpha$ dystroglycan is involved in epithelial development," Journal of Cell Biology, vol. 130, no. 1, pp. 79-91, 1995.

[7] M. Hidalgo, C. Sirour, V. Bello, N. Moreau, M. Beaudry, and T. Darribère, "In vivo analyzes of dystroglycan function during somitogenesis in Xenopus laevis," Developmental Dynamics, vol. 238, no. 6, pp. 1332-1345, 2009.

[8] S. Li, D. Edgar, R. Fässler, W. Wadsworth, and P. D. Yurchenco, "The role of laminin in embryonic cell polarization and tissue organization," Developmental Cell, vol. 4, no. 5, pp. 613-624, 2003.

[9] W.-M. Deng, M. Schneider, R. Frock, C. Castillejo-Lopez, E. A. Gaman, S. Baumgartner, and H. Ruohola-Baker, "Dystroglycan is required for polarizing the epithelial cells and the oocyte in Drosophila," Development, vol. 130, no. 1, pp. 173-184, 2003.

[10] M. Masuda-Hirata, A. Suzuki, Y. Amano, K. Yamashita, M. Ide, T. Yamanaka, M. Sakai, M. Imamura, and S. Ohno, "Intracellular polarity protein PAR-1 regulates extracellular laminin assembly by regulating the dystroglycan complex," Genes to Cells, vol. 14, no. 7, pp. 835-850, 2009.

[11] M. D. Henry, M. B. Cohen, and K. P. Campbell, "Reduced expression of dystroglycan in breast and prostate cancer," Human Pathology, vol. 32, no. 8, pp. 791-795, 2001.

[12] A. Sgambato and A. Brancaccio, "The dystroglycan complex: from biology to cancer," Journal of Cellular Physiology, vol. 205, no. 2, pp. 163-169, 2005.

[13] W. Cao, M. D. Henry, P. Borrow, H. Yamada, J. H. Elder, E. V. Ravkov, S. T. Nichol, R. W. Compans, K. P. Campbell, and M. B. A. Oldstone, "Identification of $\alpha$-dystroglycan as a receptor for lymphocytic choriomeningitis virus and Lassa fever virus," Science, vol. 282, no. 5396, pp. 2079-2081, 1998.

[14] A. Rambukkana, H. Yamada, G. Zanazzi, T. Mathus, J. L. Salzer, P. D. Yurchenco, K. P. Campbell, and V. A. Fischetti, "Role of $\alpha$-dystroglycan as a Schwann cell receptor for Mycobacterium leprae," Science, vol. 282, no. 5396, pp. 2076 2079, 1998.

[15] A. Rambukkana, S. Kunz, J. Min, K. P. Campbell, and M. B. A. Oldstone, "Targeting Schwann cells by nonlytic arenaviral infection selectively inhibits myelination," Proceedings of the National Academy of Sciences of the United States of America, vol. 100, no. 26, pp. 16071-16076, 2003.

[16] S. A. Moore, F. Saito, J. Chen, D. E. Michele, M. D. Henry, A. Messing, R. D. Cohn, S. E. Ross-Barta, S. Westra, R. E. Williamson, T. Hosl, and K. P. Campbell, "Deletion of brain dystroglycan recapitulates aspects of congenital muscular dystrophy," Nature, vol. 418, no. 6896, pp. 422-425, 2002.

[17] J. E. Schröder, M. R. Tegeler, U. Großhans, E. Porten, M. Blank, J. Lee, C. Esapa, D. J. Blake, and S. Kröger, "Dystroglycan regulates structure, proliferation and differentiation of neuroepithelial cells in the developing vertebrate CNS," Developmental Biology, vol. 307, no. 1, pp. 62-78, 2007.
[18] D. L. Sherman and P. J. Brophy, "Mechanisms of axon ensheathment and myelin growth," Nature Reviews Neuroscience, vol. 6, no. 9, pp. 683-690, 2005.

[19] K. Matsumura, H. Yamada, T. Shimizu, and K. P. Campbell, "Differential expression of dystrophin, utrophin and dystrophin-associated proteins in peripheral nerve," FEBS Letters, vol. 334, no. 3, pp. 281-285, 1993.

[20] T. J. Byers, H. G. W. Lidov, and L. M. Kunkel, "An alternative dystrophin transcript specific to peripheral nerve," Nature Genetics, vol. 4, no. 1, pp. 77-81, 1993.

[21] H. Yamada, T. Shimizu, T. Tanaka, K. P. Campbell, and K. Matsumura, "Dystroglycan is a binding protein of laminin and merosin in peripheral nerve," FEBS Letters, vol. 352, no. 1, pp. 49-53, 1994.

[22] H. Yamada, A. Chiba, T. Endo, A. Kobata, L. V. B. Anderson, H. Hori, H. Fukuta-Ohi, I. Kanazawa, K. P. Campbell, T. Shimizu, and K. Matsumura, "Characterization of dystroglycan-laminin interaction in peripheral nerve," Journal of Neurochemistry, vol. 66, no. 4, pp. 1518-1524, 1996.

[23] H. Yamada, A. J. Denzer, H. Hori, T. Tanaka, L. V. B. Anderson, S. Fujita, H. Fukuta-Ohi, T. Shimizu, M. A. Ruegg, and K. Matsumura, "Dystroglycan is a dual receptor for agrin and laminin-2 in Schwann cell membrane," Journal of Biological Chemistry, vol. 271, no. 38, pp. 23418-23423, 1996.

[24] F. Saito, T. Masaki, K. Kamakura, L. V. B. Anderson, S. Fujita, H. Fukuta-Ohi, Y. Sunada, T. Shimizu, and K. Matsumura, "Characterization of the transmembrane molecular architecture of the dystroglycan complex in Schwann cells," Journal of Biological Chemistry, vol. 274, no. 12, pp. 8240-8246, 1999.

[25] F. Saito, S. A. Moore, R. Barresi, M. D. Henry, A. Messing, S. E. Ross-Barta, R. D. Cohn, R. A. Williamson, K. A. Sluka, D. L. Sherman, P. J. Brophy, J. D. Schmelzer, P. A. Low, L. Wrabetz, M. L. Feltri, and K. P. Campbell, "Unique role of dystroglycan in peripheral nerve myelination, nodal structure, and sodium channel stabilization," Neuron, vol. 38, no. 5, pp. 747-758, 2003.

[26] M. Imamura, K. Araishi, S. Noguchi, and E. Ozawa, "A sarcoglycan-dystroglycan complex anchors Dp116 and utrophin in the peripheral nervous system," Human Molecular Genetics, vol. 9, no. 20, pp. 3091-3100, 2000.

[27] D. L. Sherman, C. Fabrizi, C. S. Gillespie, and P. J. Brophy, "Specific disruption of a Schwann cell dystrophin-related protein complex in a demyelinating neuropathy," Neuron, vol. 30, no. 3, pp. 677-687, 2001.

[28] S. Occhi, D. Zambroni, U. Del Carro, S. Amadio, E. E. Sirkowski, S. S. Scherer, K. P. Campbell, S. A. Moore, Z.-L. Chen, S. Strickland, A. Di Muzio, A. Uncini, L. Wrabetz, and M. L. Feltri, "Both laminin and Schwann cell dystroglycan are necessary for proper clustering of sodium channels at nodes of Ranvier," Journal of Neuroscience, vol. 25, no. 41, pp. 94189427, 2005.

[29] D. E. Albrecht, D. L. Sherman, P. J. Brophy, and S. C. Froehner, "The ABCA1 cholesterol transporter associates with one of two distinct dystrophin-based scaffolds in Schwann cells," Glia, vol. 56, no. 6, pp. 611-618, 2008.

[30] T. Masaki, K. Matsumura, F. Saito, Y. Sunada, T. Shimizu, H. Yorifuji, K. Motoyoshi, and K. Kamakura, "Expression of dystroglycan and laminin-2 in peripheral nerve under axonal degeneration and regeneration," Acta Neuropathologica, vol. 99, no. 3, pp. 289-295, 2000. 
[31] T. Masaki, K. Matsumura, F. Saito, H. Yamada, S. Higuchi, K. Kamakura, H. Yorifuji, and T. Shimizu, "Association of dystroglycan and laminin-2 coexpression with myelinogenesis in peripheral nerves," Medical Electron Microscopy, vol. 36, no. 4, pp. 221-239, 2003.

[32] T. Masaki, K. Matsumura, A. Hirata, H. Yamada, A. Hase, T. Shimizu, H. Yorifuji, K. Motoyoshi, and K. Kamakura, "Expression of dystroglycan complex in satellite cells of dorsal root ganglia," Acta Neuropathologica, vol. 101, no. 2, pp. 174-178, 2001.

[33] K. H. Holt, R. H. Crosbie, D. P. Venzke, and K. P. Campbell, "Biosynthesis of dystroglycan: processing of a precursor propeptide," FEBS Letters, vol. 468, no. 1, pp. 79-83, 2000.

[34] E. Hohenester, D. Tisi, J. F. Talts, and R. Timpl, "The crystal structure of a laminin G-like module reveals the molecular basis of $\alpha$-dystroglycan binding to laminins, perlecan, and agrin," Molecular Cell, vol. 4, no. 5, pp. 783-792, 1999.

[35] D. Tisi, J. F. Talts, R. Timpl, and E. Hohenester, "Structure of the C-terminal laminin G-like domain pair of the laminin $\alpha 2$ chain harbouring binding sites for $\alpha$-dystroglycan and heparin," The EMBO Journal, vol. 19, no. 7, pp. 1432-1440, 2000.

[36] J. F. Talts, T. Sasaki, N. Miosge, W. Göhring, K. Mann, R. Mayne, and R. Timpl, "Structural and functional analysis of the recombinant $\mathrm{G}$ domain of the laminin $\alpha 4$ chain and its proteolytic processing in tissues," Journal of Biological Chemistry, vol. 275, no. 45, pp. 35192-35199, 2000.

[37] J. M. Ervasti and K. P. Campbell, "A role for the dystrophinglycoprotein complex as a transmembrane linker between laminin and actin," Journal of Cell Biology, vol. 122, no. 4, pp. 809-823, 1993.

[38] A. Chiba, K. Matsumura, H. Yamada, T. Inazu, T. Shimizu, S. Kusunoki, I. Kanazawa, A. Kobata, and T. Endo, "Structures of sialylated O-linked oligosaccharides of bovine peripheral nerve $\alpha$-dystroglycan. The role of a novel O-mannosyltype oligosaccharide in the binding of $\alpha$-dystroglycan with laminin," Journal of Biological Chemistry, vol. 272, no. 4, pp. 2156-2162, 1997.

[39] A. C. Combs and J. M. Ervasti, "Enhanced laminin binding by $\alpha$-dystroglycan after enzymatic deglycosylation," Biochemical Journal, vol. 390, no. 1, pp. 303-309, 2005.

[40] H. Hall, D. Bozic, K. Michel, and J. A. Hubbell, "Nterminal $\alpha$-dystroglycan binds to different extracellular matrix molecules expressed in regenerating peripheral nerves in a protein-mediated manner and promotes neurite extension of PC12 cells," Molecular and Cellular Neuroscience, vol. 24, no. 4, pp. 1062-1073, 2003.

[41] W. Chung and J. T. Campanelli, "WW and EF hand domains of dystrophin-family proteins mediate dystroglycan binding," Molecular Cell Biology Research Communications, vol. 2, no. 3, pp. 162-171, 1999.

[42] D. J. Blake and E. Martin-Rendon, "Intermediate filaments and the function of the dystrophin-protein complex," Trends in Cardiovascular Medicine, vol. 12, no. 5, pp. 224-228, 2002.

[43] D. E. Albrecht and S. C. Froehner, "DAMAGE, a novel $\alpha$ dystrobrevin-associated MAGE protein in dystrophin complexes," Journal of Biological Chemistry, vol. 279, no. 8, pp. 7014-7023, 2004.

[44] Y.-J. Chen, H. J. Spence, J. M. Cameron, T. Jess, J. L. Ilsley, and S. J. Winder, "Direct interaction of $\beta$-dystroglycan with Factin," Biochemical Journal, vol. 375, no. 2, pp. 329-337, 2003.

[45] D. E. Albrecht and S. C. Froehner, "Syntrophins and dystrobrevins: defining the dystrophin scaffold at synapses," NeuroSignals, vol. 11, no. 3, pp. 123-129, 2002.
[46] K. Hnia, G. Hugon, A. Masmoudi, J. Mercier, F. Rivier, and D. Mornet, "Effect of $\beta$-dystroglycan processing on utrophin/Dp116 anchorage in normal and $\mathrm{mdx}$ mouse Schwann cell membrane," Neuroscience, vol. 141, no. 2, pp. 607-620, 2006.

[47] H. Yamada, F. Saito, H. Fukuta-Ohi, D. Zhong, A. Hase, K. Arai, A. Okuyama, R. Maekawa, T. Shimizu, and K. Matsumura, "Processing of $\beta$-dystroglycan by matrix metalloproteinase disrupts the link between the extracellular matrix and cell membrane via the dystroglycan complex," Human Molecular Genetics, vol. 10, no. 15, pp. 1563-1569, 2001.

[48] K. Matsumura, D. Zhong, F. Saito, K. Arai, K. Adachi, H. Kawai, I. Higuchi, I. Nishino, and T. Shimizu, "Proteolysis of $\beta$-dystroglycan in muscular diseases," Neuromuscular Disorders, vol. 15, no. 5, pp. 336-341, 2005.

[49] D. Zhong, F. Saito, Y. Saito, A. Nakamura, T. Shimizu, and K. Matsumura, "Characterization of the protease activity that cleaves the extracellular domain of $\beta$-dystroglycan," Biochemical and Biophysical Research Communications, vol. 345, no. 2, pp. 867-871, 2006.

[50] H. Cai, R. A. Erdman, L. Zweier, J. Chen, J. H. Shaw IV, K. A. Baylor, M. M. Stecker, D. J. Carey, and Y.-M. M. Chan, "The sarcoglycan complex in Schwann cells and its role in myelin stability," Experimental Neurology, vol. 205, no. 1, pp. 257-269, 2007.

[51] F. A. Court, D. L. Sherman, T. Pratt, E. M. Garry, R. R. Ribchester, D. F. Cottrell, S. M. Fleetwood-Walker, and P. J. Brophy, "Restricted growth of Schwann cells lacking Cajal bands slows conduction in myelinated nerves," Nature, vol. 431, no. 7005, pp. 191-195, 2004.

[52] F. A. Court, J. E. Hewitt, K. Davies, B. L. Patton, A. Uncini, L. Wrabetz, and M. L. Feltri, "A laminin-2, dystroglycan, utrophin axis is required for compartmentalization and elongation of myelin segments," Journal of Neuroscience, vol. 29, no. 12, pp. 3908-3919, 2009.

[53] C. Salim, Y. V. Boxberg, J. Alterio, S. Féréol, and F. Nothias, "The giant protein AHNAK involved in morphogenesis and laminin substrate adhesion of myelinating Schwann cells," Glia, vol. 57, no. 5, pp. 535-549, 2009.

[54] A. Nodari, S. C. Previtali, G. Dati, S. Occhi, F. A. Court, C. Colombelli, D. Zambroni, G. Dina, U. Del Carro, K. P. Campbell, A. Quattrini, L. Wrabetz, and M. L. Feltri, " $\alpha 6 \beta 4$ integrin and dystroglycan cooperate to stabilize the myelin sheath," Journal of Neuroscience, vol. 28, no. 26, pp. 6714-6719, 2008.

[55] A. M. Michelson, E. S. Russell, and P. J. Harman, "Dystrophia muscularis: a hereditary primary myopathy in the house mouse," Proceedings of the National Academy of Sciences of the United States of America, vol. 41, no. 12, pp. 1079-1084, 1955.

[56] W. G. Bradley and M. Jenkison, "Neural abnormalities in the dystrophic mouse," Journal of the Neurological Sciences, vol. 25, no. 2, pp. 249-255, 1975.

[57] W. G. Bradley, E. Jaros, and M. Jenkison, "The nodes of Ranvier in the nerves of mice with muscular dystrophy," Journal of Neuropathology and Experimental Neurology, vol. 36, no. 5, pp. 797-806, 1977.

[58] C. A. Stirling, "Abnormalities in Schwann cell sheaths in spinal nerve roots of dystrophic mice," Journal of Anatomy, vol. 119, no. 1, pp. 169-180, 1975.

[59] E. Jaros and W. G. Bradley, "Atypical axon-Schwann cell relationships in the common peroneal nerve of the dystrophic mouse: an ultrastructural study," Neuropathology and Applied Neurobiology, vol. 5, no. 2, pp. 133-147, 1979. 
[60] M. L. Feltri and L. Wrabetz, "Laminins and their receptors in Schwann cells and hereditary neuropathies," Journal of the Peripheral Nervous System, vol. 10, no. 2, pp. 128-143, 2005.

[61] B. L. Patton, J. H. Miner, A. Y. Chiu, and J. R. Sanes, "Distribution and function of laminins in the neuromuscular system of developing, adult, and mutant mice," Journal of Cell Biology, vol. 139, no. 6, pp. 1507-1521, 1997.

[62] B. L. Patton, B. Wang, Y. S. Tarumi, K. L. Seburn, and R. W. Burgess, "A single point mutation in the LN domain of LAMA2 causes muscular dystrophy and peripheral amyelination," Journal of Cell Science, vol. 121, no. 10, pp. 1593-1604, 2008.

[63] H. Xu, X.-R. Wu, U. M. Wewer, and E. Engval, "Murine muscular dystrophy caused by a mutation in the laminin $\alpha 2$ (Lama2) gene," Nature Genetics, vol. 8, no. 3, pp. 297-302, 1994.

[64] Y. Sunada, S. M. Bernier, A. Utani, Y. Yamada, and K. P. Campbell, "Identification of a novel mutant transcript of laminin $\alpha 2$ chain gene responsible for muscular dystrophy and dysmyelination in dy2J mice," Human Molecular Genetics, vol. 4, no. 6, pp. 1055-1061, 1995.

[65] W.-M. Yu, Z.-L. Chen, A. J. North, and S. Strickland, "Laminin is required for Schwann cell morphogenesis," Journal of Cell Science, vol. 122, no. 7, pp. 929-936, 2009.

[66] M. Nakagawa, Y. Miyagoe-Suzuki, K. Ikezoe, et al., "Schwann cell myelination occurred without basal lamina formation in laminin $\alpha 2$ chain-null mutant (dy3K/dy3K) mice," Glia, vol. 35, no. 2, pp. 101-110, 2001.

[67] D. Yang, J. Bierman, Y. S. Tarumi, Y.-P. Zhong, R. Rangwala, T. M. Proctor, Y. Miyagoe-Suzuki, S. Takeda, J. H. Miner, L. S, Sherman, B. G. Gold, and B. L. Patton, "Coordinate control of axon defasciculation and myelination by laminin-2 and-8," Journal of Cell Biology, vol. 168, no. 4, pp. 655-666, 2005.

[68] Z.-L. Chen and S. Strickland, "Laminin $\gamma 1$ is critical for Schwann cell differentiation, axon myelination, and regeneration in the peripheral nerve," Journal of Cell Biology, vol. 163, no. 4, pp. 889-899, 2003.

[69] C. S. Gillespie, D. L. Sherman, S. M. Fleetwood-Walker, D. F. Cottrell, S. Tait, E. M. Garry, V. C. J. Wallace, J. Ure, I. R. Griffiths, A. Smith, and P. J. Brophy, "Peripheral demyelination and neuropathic pain behavior in periaxindeficient mice," Neuron, vol. 26, no. 2, pp. 523-531, 2000.

[70] E. N. Levedakou, X.-J. Chen, B. Soliven, and B. Popko, "Disruption of the mouse Large gene in the enr and myd mutants results in nerve, muscle, and neuromuscular junction defects," Molecular and Cellular Neuroscience, vol. 28, no. 4, pp. 757-769, 2005.

[71] F. Saito, T. Masaki, Y. Saito, A. Nakamura, S. Takeda, T. Shimizu, T. Toda, and K. Matsumura, "Defective peripheral nerve myelination and neuromuscular junction formation in fukutin-deficient chimeric mice," Journal of Neurochemistry, vol. 101, no. 6, pp. 1712-1722, 2007.

[72] M. L. Feltri, D. G. Porta, S. C. Previtali, A. Nodari, B. Migliavacca, A. Cassetti, A. Littlewood-Evans, L. F. Reichardt, A. Messing, A. Quattrini, U. Mueller, and L. Wrabetz, "Conditional disruption of $\beta 1$ integrin in Schwann cells impedes interactions with axons," Journal of Cell Biology, vol. 156, no. 1, pp. 199-209, 2002.

[73] W. Kuang, H. Xu, P. H. Vachon, L. Liu, F. Loechel, U. M. Wewer, and E. Engvall, "Merosin-deficient congenital muscular dystrophy: partial genetic correction in two mouse models," Journal of Clinical Investigation, vol. 102, no. 4, pp. 844-852, 1998.
[74] S. C. Previtali, A. Nodari, C. Taveggia, C. Pardini, G. Dina, A. Villa, L. Wrabetz, A. Quattrini, and M. L. Feltri, "Expression of laminin receptors in Schwann cell differentiation: evidence for distinct roles," Journal of Neuroscience, vol. 23, no. 13, pp. 5520-5530, 2003.

[75] K. I. Gawlik, J.-Y. Li, A. Petersén, and M. Durbeej, "Laminin $\alpha 1$ chain improves laminin $\alpha 2$ chain deficient peripheral neuropathy," Human Molecular Genetics, vol. 15, no. 18, pp. 2690-2700, 2006.

[76] S. Einheber, T. A. Milner, F. Giancotti, and J. L. Salzer, "Axonal regulation of Schwann cell integrin expression suggests a role for $\alpha 6 \beta 4$ in myelination," Journal of Cell Biology, vol. 123, no. 5, pp. 1223-1236, 1993.

[77] C. Fernandez-Valle, L. Gwynn, P. M. Wood, S. Carbonetto, and M. B. Bunge, "Anti- $\beta 1$ integrin antibody inhibits Schwann cell myelination," Journal of Neurobiology, vol. 25, no. 10, pp. 1207-1226, 1994.

[78] M. L. Feltri, S. S. Scherer, R. Nemni, J. Kamholz, H. Vogelbacker, M. O. Scott, N. Canal, V. Quaranta, and L. Wrabetz, " $\beta 4$ integrin expression in myelinating Schwann cells is polarized, developmentally regulated and axonally dependent," Development, vol. 120, no. 5, pp. 1287-1301, 1994.

[79] D. E. Michele, R. Barresi, M. Kanagawa, F. Salto, R. D. Cohn, J. S. Satz, J. Dollar, I. Nishino, R. I. Kelley, H. Somer, V. Straub, K. D. Mathews, S. A. Moore, and K. P. Campbell, "Post-translational disruption of dystroglycan-ligand interactions in congenital muscular dystrophies," Nature, vol. 418, no. 6896, pp. 417-422, 2002.

[80] D.-S. Kim, Y. K. Hayashi, H. Matsumoto, M. Ogawa, S. Noguchi, N. Murakami, R. Sakuta, M. Mochizuki, D. E. Michele, K. P. Campbell, I. Nonaka, and I. Nishino, "POMT1 mutation results in defective glycosylation and loss of laminin-binding activity in $\alpha$-DG," Neurology, vol. 62, no. 6, pp. 1009-1011, 2004.

[81] T. Toda, K. Kobayashi, S. Takeda, J. Sasaki, H. Kurahashi, H. Kano, M. Tachikawa, F. Wang, Y. Nagai, K. Taniguchi, M. Taniguchi, Y. Sunada, T. Terashima, T. Endo, and K. Matsumura, "Fukuyama-type congenital muscular dystrophy (FCMD) and alpha-dystroglycanopathy," Congenital Anomalies, vol. 43, no. 2, pp. 97-104, 2003.

[82] T. Toda, T. Chiyonobu, H. Xiong, M. Tachikawa, K. Kobayashi, H. Manya, S. Takeda, M. Taniguchi, H. Kurahashi, and T. Endo, "Fukutin and $\alpha$-dystroglycanopahties," Acta Myologica, vol. 24, no. 2, pp. 60-63, 2005.

[83] E. Mercuri, S. Messina, C. Bruno, M. Mora, E. Pegoraro, G. P. Comi, A. D'Amico, C. Aiello, R. Biancheri, A. Berardinelli, P. Boffi, D. Cassandrini, A. Laverda, M. Moggio, L. Morandi, I. Moroni, M. Pane, R. Pezzani, A. Pichiecchio, A. Pini, C. Minetti, T. Mongini, E. Mottarelli, E. Ricci, A. Ruggieri, S. Saredi, C. Scuderi, A. Tessa, A. Toscano, G. Tortorella, C. P. Trevisan, C. Uggetti, G. Vasco, F. M. Santorelli, and E. Bertini, "Congenital muscular dystrophies with defective glycosylation of dystroglycan: a population study," Neurology, vol. 72, no. 21, pp. 1802-1809, 2009.

[84] R. P. Bunge, M. B. Bunge, and C. F. Eldridge, "Linkage between axonal ensheathment and basal lamina production by Schwann cells," Annual Review of Neuroscience, vol. 9, pp. 305-328, 1986.

[85] C. F. Eldridge, M. B. Bunge, and R. P. Bunge, "Differentiation of axon-related Schwann cells in vitro: II. Control of myelin formation by basal lamina," Journal of Neuroscience, vol. 9, no. 2, pp. 625-638, 1989. 
[86] K. Matsumura, H. Yamada, F. Saito, Y. Sunada, and T. Shimizu, "Peripheral nerve involvement in merosin-deficient congenital muscular dystrophy and dy mouse," Neuromuscular Disorders, vol. 7, no. 1, pp. 7-12, 1997.

[87] T. Masaki, K. Matsumura, A. Hirata, H. Yamada, A. Hase, K. Arai, T. Shimizu, H. Yorifuji, K. Motoyoshi, and K. Kamakura, "Expression of dystroglycan and the laminin- $\alpha 2$ chain in the rat peripheral nerve during development," Experimental Neurology, vol. 174, no. 1, pp. 109-117, 2002.

[88] A. Rambukkana, J. L. Salzer, P. D. Yurchenco, and E. I. Tuomanen, "Neural targeting of Mycobacterium leprae mediated by the $\mathrm{G}$ domain of the laminin- $\alpha 2$ chain," Cell, vol. 88, no. 6, pp. 811-821, 1997.

[89] S. Kunz, N. Sevilla, D. B. McGavern, K. P. Campbell, and M. B. A. Oldstone, "Molecular analysis of the interaction of LCMV with its cellular receptor $\alpha$-dystroglycan," Journal of Cell Biology, vol. 155, no. 2, pp. 301-310, 2001.

[90] S. Kunz, J. M. Rojek, M. Perez, C. F. Spiropoulou, and M. B. A. Oldstone, "Characterization of the interaction of lassa fever virus with its cellular receptor $\alpha$-dystroglycan," Journal of Virology, vol. 79, no. 10, pp. 5979-5987, 2005.

[91] A. Rambukkana, G. Zanazzi, N. Tapinos, and J. L. Salzer, "Contact-dependent demyelination by Mycobacterium leprae in the absence of immune cells," Science, vol. 296, no. 5569, pp. 927-931, 2002.

[92] N. Tapinos, M. Ohnishi, and A. Rambukkana, "ErbB2 receptor tyrosine kinase signaling mediates early demyelination induced by leprosy bacilli," Nature Medicine, vol. 12, no. 8, pp. 961-966, 2006.

[93] H. Colognato, J. Galvin, Z. Wang, J. Relucio, T. Nguyen, D. Harrison, P. D. Yurchenco, and C. Ffrench-Constant, "Identification of dystroglycan as a second laminin receptor in oligodendrocytes, with a role in myelination," Development, vol. 134, no. 9, pp. 1723-1736, 2007.

[94] Y. Miyagoe-Suzuki, M. Nakagawa, and S. Takeda, "Merosin and congenital muscular dystrophy," Microscopy Research and Technique, vol. 48, no. 3-4, pp. 181-191, 2000.

[95] S. J. Chun, M. N. Rasband, R. L. Sidman, A. A. Habib, and T. Vartanian, "Integrin-linked kinase is required for laminin-2-induced oligodendrocyte cell spreading and CNS myelination," Journal of Cell Biology, vol. 163, no. 2, pp. 397-408, 2003.

[96] R. P. Bunge, M. B. Bunge, and M. Bates, "Movements of the Schwann cell nucleus implicate progression of the inner (axon-related) Schwann cell process during myelination," Journal of Cell Biology, vol. 109, no. 1, pp. 273-284, 1989.

[97] R. Han, M. Kanagawa, T. Yoshida-Moriguchi, E. P. Rader, R. A. Ng, D. E. Michele, D. E. Muirhead, S. Kunz, S. A. Moore, S. T. Iannaccone, K. Miyake, P. L. McNeil, U. Mayer, M. B. A. Oldstoned, J. A. Faulkner, and K. P. Campbell, "Basal lamina strengthens cell membrane integrity via the laminin G domain-binding motif of $\alpha$-dystroglycan," Proceedings of the National Academy of Sciences of the United States of America, vol. 106, no. 31, pp. 12573-12579, 2009.

[98] K. Matsumura, A. Chiba, H. Yamada, H. Fukuta-Ohi, S. Fujita, T. Endo, A. Kobata, L. V. B. Anderson, I. Kanazawa, K. P. Campbell, and T. Shimizu, "A role of dystroglycan in schwannoma cell adhesion to laminin," Journal of Biological Chemistry, vol. 272, no. 21, pp. 13904-13910, 1997.

[99] J. L. Podratz, E. Rodriguez, and A. J. Windebank, "Role of the extracellular matrix in myelination of peripheral nerve," Glia, vol. 35, no. 1, pp. 35-40, 2001.
[100] M. A. Chernousov, W. M. Yu, Z. L. Chen, D. J. Carey, and S. Strickland, "Regulation of Schwann cell function by the extracellular matrix," Glia, vol. 56, no. 14, pp. 1498-1507, 2008.

[101] M. James, A. Nuttall, J. L. Ilsley, K. Ottersbach, J. M. Tinsley, M. Sudol, and S. J. Winder, "Adhesion-dependent tyrosine phosphorylation of $\beta$-dystroglycan regulates its interaction with utrophin," Journal of Cell Science, vol. 113, no. 10, pp. 1717-1726, 2000.

[102] J. L. Ilsley, M. Sudol, and S. J. Winder, "The interaction of dystrophin with $\beta$-dystroglycan is regulated by tyrosine phosphorylation," Cellular Signalling, vol. 13, no. 9, pp. 625-632, 2001.

[103] B. Yang, D. Jung, D. Motto, J. Meyer, G. Koretzky, and K. P. Campbell, "SH3 domain-mediated interaction of dystroglycan and Grb2," Journal of Biological Chemistry, vol. 270, no. 20, pp. 11711-11714, 1995.

[104] M. Cavaldesi, G. Macchia, S. Barca, P. Defilippi, G. Tarone, and T. C. Petrucci, "Association of the dystroglycan complex isolated from bovine brain synaptosomes with proteins involved in signal transduction," Journal of Neurochemistry, vol. 72, no. 4, pp. 1648-1655, 1999.

[105] K. Russo, E. Di Stasio, G. Macchia, G. Rosa, A. Brancaccio, and T. C. Petrucci, "Characterization of the $\beta$-dystroglycangrowth factor receptor 2 (Grb2) interaction," Biochemical and Biophysical Research Communications, vol. 274, no. 1, pp. 93-98, 2000.

[106] F. Sotgia, H. Lee, M. T. Bedford, T. Petrucci, M. Sudol, and M. P. Lisanti, "Tyrosine phosphorylation of $\beta$-dystroglycan at its WW domain binding motif, PPxY, recruits SH2 domain containing proteins," Biochemistry, vol. 40, no. 48, pp. 14585-14592, 2001.

[107] H. J. Spence, A. S. Dhillon, M. James, and S. Winder, "Dystroglycan, a scaffold for the ERK-MAP kinase cascade," EMBO Reports, vol. 5, no. 5, pp. 484-489, 2004.

[108] C. L. Batchelor and S. J. Winder, "Sparks, signals and shock absorbers: how dystrophin loss causes muscular dystrophy," Trends in Cell Biology, vol. 16, no. 4, pp. 198-205, 2006.

[109] C. L. Batchelor, J. R. Higginson, Y.-J. Chen, C. Vanni, A. Eva, and S. J. Winder, "Recruitment of Dbl by ezrin and dystroglycan drives membrane proximal Cdc42 activation and filopodia formation," Cell Cycle, vol. 6, no. 3, pp. 353-363, 2007.

[110] N. P. J. Vogtländer, H. J. Visch, M. A. H. Bakker, J. H. M. Berden, and J. van der Vlag, "Ligation of $\alpha$-dystroglycan on podocytes induces intracellular signaling: a new mechanism for podocyte effacement?" PLoS ONE, vol. 4, no. 6, article e5979, 2009.

[111] Y. W. Zhou, S. A. Oak, S. E. Senogles, and H. W. Jarrett, "Laminin-alphal globular domains 3 and 4 induce heterotrimeric $\mathrm{G}$ protein binding to alpha-syntrophin's PDZ domain and alter intracellular $\mathrm{Ca}^{2+}$ in muscle," American Journal of Physiology, vol. 288, no. 2, pp. C377-C388, 2005.

[112] K. J. Langenbach and T. A. Rando, "Inhibition of dystroglycan binding to laminin disrupts the PI3K/AKT pathway and survival signaling in muscle cells," Muscle and Nerve, vol. 26, no. 5, pp. 644-653, 2002.

[113] Y. Zhou, D. Jiang, D. B. Thomason, and H. W. Jarrett, "Laminin-induced activation of Racl and JNKp46 is initiated by Src family kinases and mimics the effects of skeletal muscle contraction," Biochemistry, vol. 46, no. 51, pp. 14907-14916, 2007. 
[114] Y. Xiong, Y. Zhou, and H. W. Jarrett, "Dystrophin glycoprotein complex-associated $\mathrm{G} \beta \gamma$ subunits activate phosphatidylinositol-3-kinase/akt signaling in skeletal muscle in a laminin-dependent manner," Journal of Cellular Physiology, vol. 219, no. 2, pp. 402-414, 2009.

[115] S. A. Oak, Y. W. Zhou, and H. W. Jarrett, "Skeletal muscle signaling pathway through the dystrophin glycoprotein complex and Rac1," Journal of Biological Chemistry, vol. 278, no. 41, pp. 39287-39295, 2003.

[116] M. M. Kucherenko, M. Pantoja, A. S. Yatsenko, H. R. Shcherbata, K. A. Fischer, D. V. Maksym IV, Y. I. Chernyk, and H. Ruohola-Baker, "Genetic modifier screens reveal new components that interact with the Drosophila dystroglycandystrophin complex," PLoS ONE, vol. 3, no. 6, article e2418, 2008.

[117] S. Li, P. Liquari, K. K. McKee, D. Harrison, R. Patel, S. Lee, and P. D. Yurchenco, "Laminin-sulfatide binding initiates basement membrane assembly and enables receptor signaling in Schwann cells and fibroblasts," Journal of Cell Biology, vol. 169, no. 1, pp. 179-189, 2005.

[118] P. Guicheney, N. Vignier, A. Helbling-Leclerc, M. Nissinen, X. Zhang, C. Cruaud, J.-C. Lambert, C. Richelme, H. Topaloglu, L. Merlini, A. Barois, K. Schwartz, F. M. S. Tomé, K. Tryggvason, and M. Fardeau, "Genetics of laminin $\alpha 2$ chain (or merosin) deficient congenital muscular dystrophy: from identification of mutations to prenatal diagnosis," Neuromuscular Disorders, vol. 7, no. 3, pp. 180-186, 1997.

[119] Z. Shorer, J. Philpot, F. Muntoni, C. Sewry, and V. Dubowitz, "Demyelinating peripheral neuropathy in merosin-deficient congenital muscular dystrophy," Journal of Child Neurology, vol. 10, no. 6, pp. 472-475, 1995.

[120] M. Mora, I. Moroni, G. Uziel, C. Di Blasi, R. Barresi, L. Farina, and L. Morandi, "Mild clinical phenotype in a 12year-old boy with partial merosin deficiency and central and peripheral nervous system abnormalities," Neuromuscular Disorders, vol. 6, no. 5, pp. 377-381, 1996.

[121] A. Di Muzio, M. V. De Angelis, P. Di Fulvio, A. Ratti, A. Pizzuti, L. Stuppia, D. Gambi, and A. Uncini, "Dysmyelinating sensory-motor neuropathy in merosindeficient congenital muscular dystrophy," Muscle and Nerve, vol. 27, no. 4, pp. 500-506, 2003.

[122] S. Quijano-Roy, F. Renault, N. Romero, P. Guicheney, M. Fardeau, and B. Estournet, "EMG and nerve conduction studies in children with congenital muscular dystrophy," Muscle and Nerve, vol. 29, no. 2, pp. 292-299, 2004.

[123] Y. K. R. Habeeb, M. Al-Bloushi, E. S. Al-Jumah, T. M. De Souza, and A. Moosa, "Congenital muscular dystrophy in Arab children," Journal of Child Neurology, vol. 21, no. 5, pp. 400-405, 2006.

[124] F. Deodato, M. Sabatelli, E. Ricci, E. Mercuri, F. Muntoni, C. Sewry, I. Naom, P. Tonali, and F. Guzzetta, "Hypermyelinating neuropathy, mental retardation and epilepsy in a case of merosin deficiency," Neuromuscular Disorders, vol. 12, no. 4, pp. 392-398, 2002.

[125] M. Vainzof, S. K. N. Marie, U. C. Reed, J. S. Schwartzmann, R. C. M. Pavanello, M. R. Passos-Bueno, and M. Zatz, "Deficiency of merosin (laminin $\mathrm{M}$ or $\alpha 2$ ) in congenital muscular dystrophy associated with cerebral white matter alterations," Neuropediatrics, vol. 26, no. 6, pp. 293-297, 1995.

[126] C. P. Trevisan, F. Martinello, E. Ferruzza, M. Fanin, M. Chevallay, and F. M. S. Tomé, "Brain alterations in the classical form of congenital muscular dystrophy. Clinical and neuroimaging follow-up of 12 cases and correlation with the expression of merosin in muscle," Child's Nervous System, vol. 12, no. 10, pp. 604-610, 1996.

[127] T. Haenggi and J.-M. Fritschy, "Role of dystrophin and utrophin for assembly and function of the dystrophin glycoprotein complex in non-muscle tissue," Cellular and Molecular Life Sciences, vol. 63, no. 14, pp. 1614-1631, 2006.

[128] F. Muntoni, S. Torelli, and M. Brockington, "Muscular dystrophies due to glycosylation defects," Neurotherapeutics, vol. 5, no. 4, pp. 627-632, 2008.

[129] T. Yamamoto, Y. Kato, M. Kawaguchi-Niida, N. Shibata, M. Osawa, K. Saito, S. Kröger, and M. Kobayashi, "Characteristics of neurons and glia in the brain of Fukuyama type congenital muscular dystrophy," Acta Myologica, vol. 27, pp. 9-13, 2008.

[130] A. Waite, C. L. Tinsley, M. Locke, and D. J. Blake, "The neurobiology of the dystrophin-associated glycoprotein complex," Annals of Medicine, vol. 41, no. 5, pp. 344-359, 2009.

[131] V. Delague, C. Bareil, S. Tuffery, P. Bouvagnet, E. Chouery, S. Koussa, T. Maisonobe, J. Loiselet, A. Mégarbané, and M. Claustres, "Mapping of a new locus for autosomal recessive demyelinating charcot- marie-tooth disease to 19q13.1-13.3 in a large consanguineous Lebanese family: exclusion of MAG as a candidate gene," American Journal of Human Genetics, vol. 67, no. 1, pp. 236-243, 2000.

[132] C. F. Boerkoel, H. Takashima, P. Stankiewicz, C. A. Garcia, S. M. Leber, L. Rhee-Morris, and J. R. Lupski, "Periaxin mutations cause recessive dejerine-sottas neuropathy," American Journal of Human Genetics, vol. 68, no. 2, pp. 325-333, 2001.

[133] A. Guilbot, A. Williams, N. Ravisé, C. Verny, A. Brice, D. L. Sherman, P. J. Brophy, E. LeGuern, V. Delague, C. Bareil, A. Mégarbané, and M. Claustres, "A mutation in periaxin is responsible for CMT4F, an autosomal recessive form of Charcot-Marie-Tooth disease," Human Molecular Genetics, vol. 10, no. 4, pp. 415-421, 2001.

[134] H. Takashima, C. F. Boerkoel, P. De Jonghe, C. Ceuterick, J.-J. Martin, T. Voit, J. M. Schröder, A. Williams, P. J. Brophy, V. Timmerman, and J. R. Lupski, "Periaxin mutations cause a broad spectrum of demyelinating neuropathies," Annals of Neurology, vol. 51, no. 6, pp. 709-715, 2002.

[135] K. R. Jessen and R. Mirsky, "Negative regulation of myelination: relevance for development, injury, and demyelinating disease," Glia, vol. 56, no. 14, pp. 1552-1565, 2008.

[136] R. Mirsky, A. Woodhoo, D. B. Parkinson, P. Arthur-Farraj, A. Bhaskaran, and K. R. Jessen, "Novel signals controlling embryonic Schwann cell development, myelination and dedifferentiation," Journal of the Peripheral Nervous System, vol. 13, no. 2, pp. 122-135, 2008.

[137] X. Chen, H. Xu, P. Yuan, F. Fang, M. Huss, V. B. Vega, E. Wong, Y. L. Orlov, W. Zhang, J. Jiang, Y.-H. Loh, H. C. Yeo, Z. X. Yeo, V. Narang, K. R. Govindarajan, B. Leong, A. Shahab, Y. Ruan, G. Bourque, W.-K. Sung, N. D. Clarke, C.-L. Wei, and H.-H. Ng, "Integration of external signaling pathways with the core transcriptional network in embryonic stem cells," Cell, vol. 133, no. 6, pp. 1106-1117, 2008.

[138] F.-J. Müller, L. C. Laurent, D. Kostka, I. Ulitsky, R. Williams, C. Lu, I.-H. Park, M. S. Rao, R. Shamir, P. H. Schwartz, N. O. Schmidt, and J. F. Loring, "Regulatory networks define phenotypic classes of human stem cell lines," Nature, vol. 455, no. 7211, pp. 401-405, 2008.

[139] M. Gstaiger and R. Aebersold, "Applying mass spectrometrybased proteomics to genetics, genomics and network biology," Nature Reviews Genetics, vol. 10, no. 9, pp. 617-627, 2009. 
[140] J. L. Salzer, "Polarized domains of myelinated axons," Neuron, vol. 40, no. 2, pp. 297-318, 2003.

[141] J. L. Salzer, P. J. Brophy, and E. Peles, "Molecular domains of myelinated axons in the peripheral nervous system," Glia, vol. 56, no. 14, pp. 1532-1540, 2008.

[142] M. A. Bowe, D. B. Mendis, and J. R. Fallon, "The small leucine-rich repeat proteoglycan biglycan binds to $\alpha$ dystroglycan and is upregulated in dystrophic muscle," Journal of Cell Biology, vol. 148, no. 4, pp. 801-810, 2000.

[143] J. F. Talts, Z. Andac, W. Göhring, A. Brancaccio, and R. Timpl, "Binding of the $\mathrm{G}$ domains of laminin $\alpha 1$ and $\alpha 2$ chains and perlecan to heparin, sulfatides, $\alpha$-dystroglycan and several extracellular matrix proteins," The EMBO Journal, vol. 18, no. 4, pp. 863-870, 1999.

[144] M. D. Henry, J. S. Satz, C. Brakebusch, M. Costell, E. Gustafsson, R. Fässler, and K. P. Campbell, "Distinct roles for dystroglycan, $\beta 1$ integrin and perlecan in cell surface laminin organization," Journal of Cell Science, vol. 114, no. 6, pp. 1137-1144, 2001.

[145] V. Mirouse, C. P. Christoforou, C. Fritsch, D. St. Johnston, and R. P. Ray, "Dystroglycan and perlecan provide a basal cue required for epithelial polarity during energetic stress," Developmental Cell, vol. 16, no. 1, pp. 83-92, 2009.

[146] S. Sato, Y. Omori, K. Katoh, M. Kondo, M. Kanagawa, K. Miyata, K. Funabiki, T. Koyasu, N. Kajimura, T. Miyoshi, H. Sawai, K. Kobayashi, A. Tani, T. Toda, J. Usukura, Y. Tano, T. Fujikado, and T. Furukawa, "Pikachurin, a dystroglycan ligand, is essential for photoreceptor ribbon synapse formation," Nature Neuroscience, vol. 11, no. 8, pp. 923-931, 2008.

[147] P. D. Côté, H. Moukhles, and S. Carbonetto, "Dystroglycan is not required for localization of dystrophin, syntrophin, and neuronal nitric-oxide synthase at the sarcolemma but regulates integrin $\alpha 7 \mathrm{~B}$ expression and caveolin-3 distribution," Journal of Biological Chemistry, vol. 277, no. 7, pp. 4672-4679, 2002.

[148] A. Driss, L. Charrier, Y. Yan, V. Nduati, S. Sitaraman, and D. Merlin, "Dystroglycan receptor is involved in integrin activation in intestinal epithelia," American Journal of Physiology, vol. 290, no. 6, pp. G1228-G1242, 2006.

[149] E. Guadagno and H. Moukhles, "Laminin-induced aggregation of the inwardly rectifying potassium channel, Kir4.1, and the water-permeable channel, AQP4, via a dystroglycan-containing complex in astrocytes," Glia, vol. 47, no. 2, pp. 138-149, 2004.

[150] G. P. Nicchia, L. Cogotzi, A. Rossi, et al., "Expression of multiple AQP4 pools in the plasma membrane and their association with the dystrophin complex," Journal of Neurochemistry, vol. 105, no. 6, pp. 2156-2165, 2008.

[151] E. Ambrosini, B. Serafini, A. Lanciotti, F. Tosini, F. Scialpi, R. Psaila, C. Raggi, F. Di Girolamo, T. C. Petrucci, and F. Aloisi, "Biochemical characterization of MLC1 protein in astrocytes and its association with the dystrophin-glycoprotein complex," Molecular and Cellular Neuroscience, vol. 37, no. 3, pp. 480-493, 2008.

[152] D. J. Blake, A. Weir, S. E. Newey, and K. E. Davies, "Function and genetics of dystrophin and dystrophin-related proteins in muscle," Physiological Reviews, vol. 82, no. 2, pp. 291-329, 2002.

[153] Y. Eshed, K. Feinberg, S. Poliak, H. Sabanay, O. Sarig-Nadir, I. Spiegel, J. R. Bermingham Jr., and E. Peles, "Gliomedin mediates Schwann cell-axon interaction and the molecular assembly of the nodes of Ranvier," Neuron, vol. 47, no. 2, pp. 215-229, 2005.
[154] G. Noël, M. Belda, E. Guadagno, J. Micoud, N. Klöcker, and H. Moukhles, "Dystroglycan and Kir4.1 coclustering in retinal Müller glia is regulated by laminin-1 and requires the PDZ-ligand domain of Kir4.1," Journal of Neurochemistry, vol. 94, no. 3, pp. 691-702, 2005.

[155] K. W. Prins, J. L. Humston, A. Mehta, V. Tate, E. Ralston, and J. M. Ervasti, "Dystrophin is a microtubule-associated protein," Journal of Cell Biology, vol. 186, no. 3, pp. 363-369, 2009.

[156] A. Hall, "Rho GTPases and the control of cell behaviour," Biochemical Society Transactions, vol. 33, no. 5, pp. 891-895, 2005.

[157] T. Rosenbaum, H. A. Kim, Y. L. Boissy, B. Ling, and N. Ratner, "Neurofibromin, the neurofibromatosis type 1 RaS-GAP, is required for appropriate P0 expression and myelination," Annals of the New York Academy of Sciences, vol. 883, pp. 203-214, 1999.

[158] M. C. Harrisingh, E. Perez-Nadales, D. B. Parkinson, D. S. Malcolm, A. W. Mudge, and A. C. Lloyd, "The Ras/Raf/ERK signalling pathway drives Schwann cell dedifferentiation," The EMBO Journal, vol. 23, no. 15, pp. 3061-3071, 2004.

[159] A. Woodhoo, M. B. D. Alonso, A. Droggiti, M. Turmaine, M. D’Antonio, D. B. Parkinson, D. K. Wilton, R. Al-Shawi, P. Simons, J. Shen, F. Guillemot, F. Radtke, D. Meijer, M. L. Feltri, L. Wrabetz, R. Mirsky, and K. R. Jessen, "Notch controls embryonic Schwann cell differentiation, postnatal myelination and adult plasticity," Nature Neuroscience, vol. 12, no. 7, pp. 839-847, 2009.

[160] F. Ye, Y. Chen, T. Hoang, R. L. Montgomery, X.-H. Zhao, H. Bu, T. Hu, M. M. Taketo, J. H. Van Es, H. Clevers, J. Hsieh, R. Bassel-Duby, E. N. Olson, and Q. R. Lu, "HDAC1 and HDAC2 regulate oligodendrocyte differentiation by disrupting the $\beta$-catenin-TCF interaction," Nature Neuroscience, vol. 12, no. 7, pp. 829-838, 2009.

[161] H. Li and W. D. Richardson, "Genetics meets epigenetics: HDACs and Wnt signaling in myelin development and regeneration," Nature Neuroscience, vol. 12, no. 7, pp. 815-817, 2009.

[162] P. Topilko, S. Schneider-Maunoury, G. Levi, A. Baron-Van Evercooren, A. B. Younes Chennoufi, T. Seitanidou, C. Babinet, and P. Charnay, "Krox-20 controls myelination in the peripheral nervous system," Nature, vol. 371, no. 6500, pp. 796-799, 1994.

[163] W.-M. Yu, M. L. Feltri, L. Wrabetz, S. Strickland, and Z.-L. Chen, "Schwann cell-specific ablation of laminin $\gamma 1$ causes apoptosis and prevents proliferation," Journal of Neuroscience, vol. 25, no. 18, pp. 4463-4472, 2005.

[164] D. B. Parkinson, A. Bhaskaran, A. Droggiti, S. Dickinson, M. D’Antonio, R. Mirsky, and K. R. Jessen, "Krox-20 inhibits Jun-NH2-terminal kinase/c-Jun to control Schwann cell proliferation and death," Journal of Cell Biology, vol. 164, no. 3, pp. 385-394, 2004.

[165] D. Ilić, C. H. Damsky, and T. Yamamoto, "Focal adhesion kinase: at the crossroads of signal transduction," Journal of Cell Science, vol. 110, no. 4, pp. 401-407, 1997.

[166] M. Grove, N. H. Komiyama, K.-A. Nave, S. G. Grant, D. L. Sherman, and P. J. Brophy, "FAK is required for axonal sorting by Schwann cells," Journal of Cell Biology, vol. 176, no. 3, pp. 277-282, 2007.

[167] T. Vartanian, A. Goodearl, S. Lefebvre, S.-K. Park, and G. Fischbach, "Neuregulin induces the rapid association of focal adhesion kinase with the erbB2-erbB3 receptor complex in Schwann cells," Biochemical and Biophysical Research Communications, vol. 271, no. 2, pp. 414-417, 2000. 
[168] A. Rettino, F. Rafaneli, G. Genovese, et al., "Identification of SP1 and GC-boxes as transcriptional regulators of mouse Dag-1 gene promoter," American Journal of Physiology Cell Physiology, vol. 297, no. 5, pp. C1113-1123, 2009.

[169] P. Miura, J. V. Chakkalakal, L. Boudreault, et al., "Pharmacological activation of $\operatorname{PPAR} \beta / \delta$ stimulates utrophin A expression in skeletal muscle fibers and restores sarcolemmal integrity in mature mdx mice," Human Molecular Genetics, vol. 18, no. 23, pp. 4640-4649, 2009.

[170] B. E. Bernstein, A. Meissner, and E. S. Lander, "The mammalian epigenome," Cell, vol. 128, no. 4, pp. 669-681, 2007.

[171] C. V. Melendez-Vasquez, J. C. Rios, G. Zanazzi, S. Lambert, A. Bretscher, and J. L. Salzer, "Nodes of Ranvier form in association with ezrin-radixin-moesin (ERM)-positive Schwann cell processes," Proceedings of the National Academy of Sciences of the United States of America, vol. 98, no. 3, pp. 1235-1240, 2001.

[172] S. Etienne-Manneville, "Polarity proteins in glial cell functions," Current Opinion in Neurobiology, vol. 18, no. 5, pp. $488-494,2008$. 


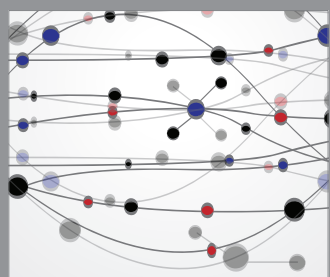

The Scientific World Journal
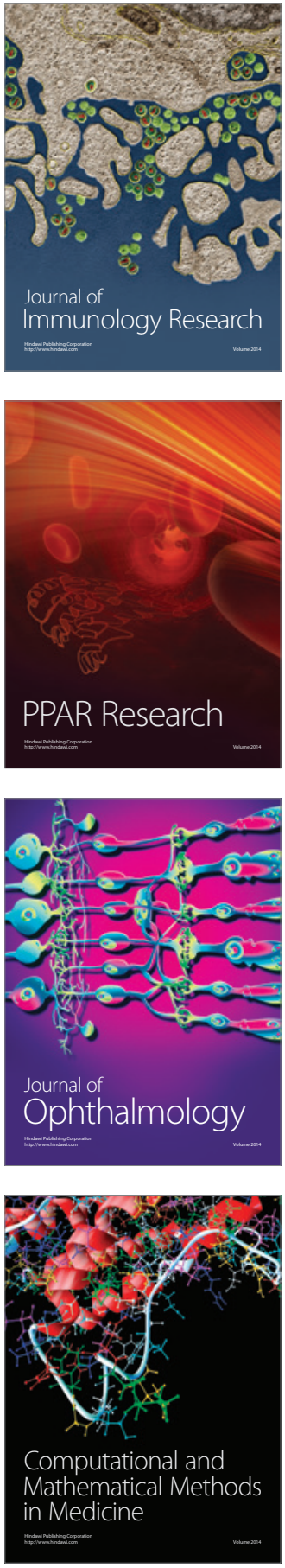

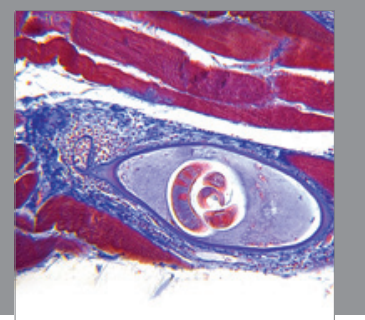

Gastroenterology

Research and Practice
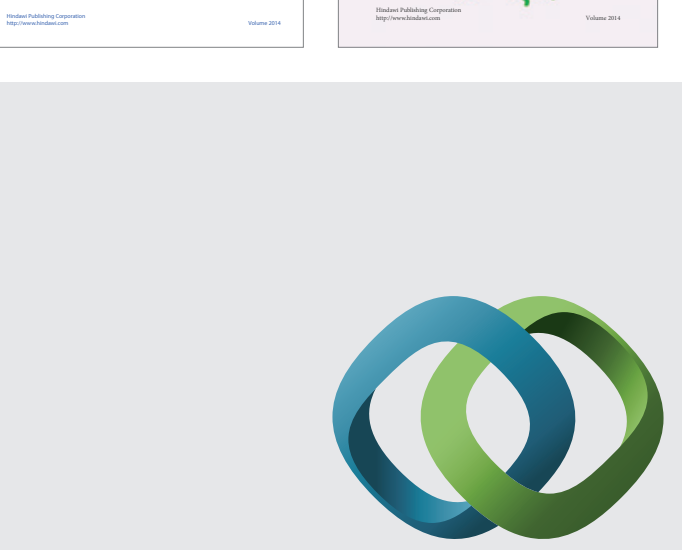

\section{Hindawi}

Submit your manuscripts at

http://www.hindawi.com
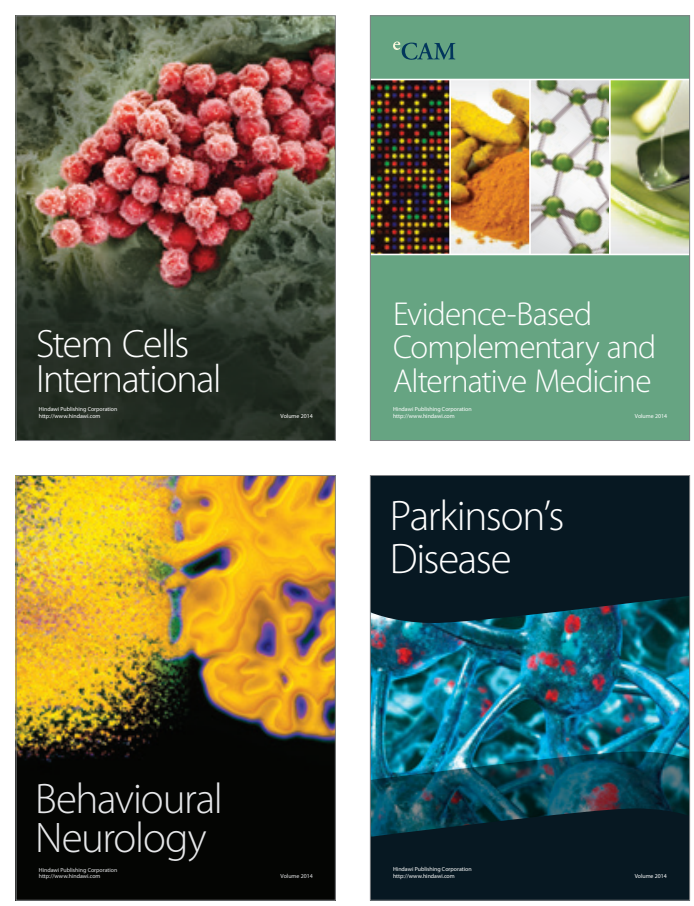

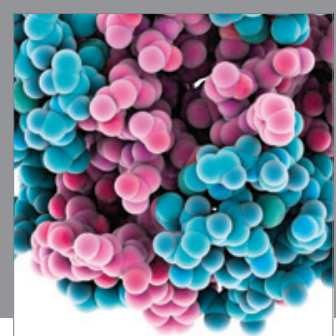

Journal of
Diabetes Research

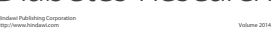

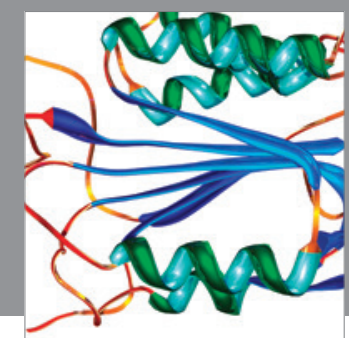

Disease Markers
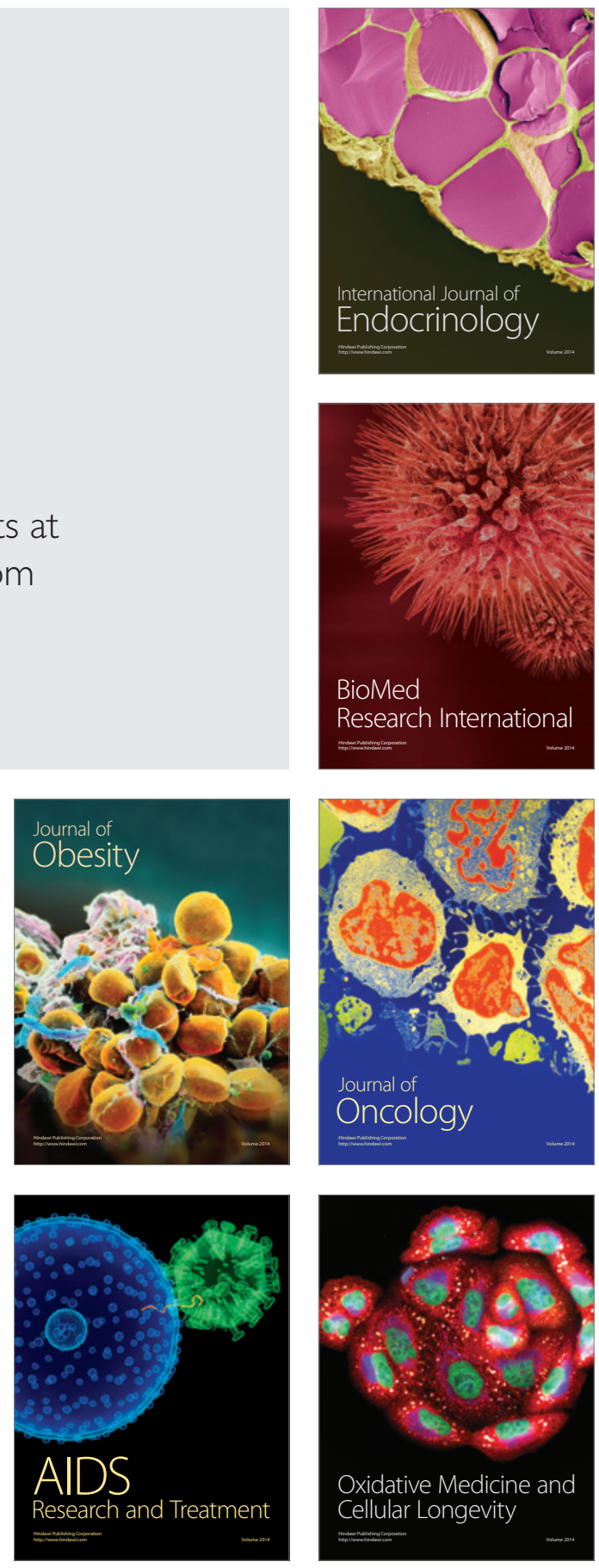